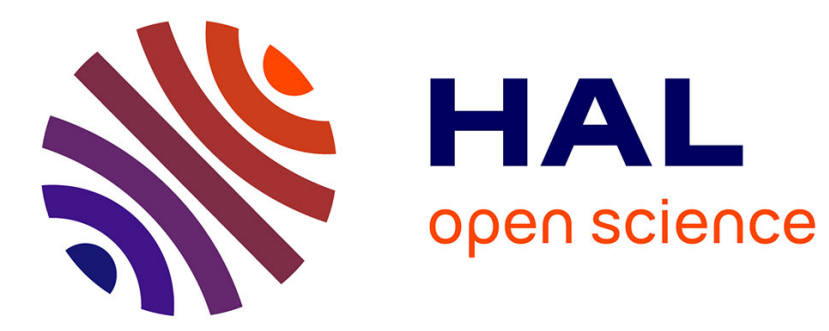

\title{
Quaternary coastal uplift along the Talara Arc (Ecuador, Northern Peru) from new marine terrace data
}

Kevin Pedoja, L. Ortlieb, J.-F. Dumont, M. Lamothe, Bassam Ghaleb, M.

Auclair, B. Labrousse

\section{- To cite this version:}

Kevin Pedoja, L. Ortlieb, J.-F. Dumont, M. Lamothe, Bassam Ghaleb, et al.. Quaternary coastal uplift along the Talara Arc (Ecuador, Northern Peru) from new marine terrace data. Marine Geology, 2006, 228 (1-4), pp.73-91. 10.1016/j.margeo.2006.01.004 . hal-00407620

\section{HAL Id: hal-00407620 \\ https://hal.science/hal-00407620}

Submitted on 23 Sep 2019

HAL is a multi-disciplinary open access archive for the deposit and dissemination of scientific research documents, whether they are published or not. The documents may come from teaching and research institutions in France or abroad, or from public or private research centers.
L'archive ouverte pluridisciplinaire HAL, est destinée au dépôt et à la diffusion de documents scientifiques de niveau recherche, publiés ou non, émanant des établissements d'enseignement et de recherche français ou étrangers, des laboratoires publics ou privés. 


\title{
Quaternary coastal uplift along the Talara Arc (Ecuador, Northern Peru) from new marine terrace data
}

\author{
K. Pedoja ${ }^{\text {a,* }}$, L. Ortlieb ${ }^{\text {b }}$, J.F. Dumont ${ }^{\text {a }}$, M. Lamothe ${ }^{\text {c }}$, B. Ghaleb ${ }^{\mathrm{d}}$, \\ M. Auclair ${ }^{c}$, B. Labrousse ${ }^{\text {a }}$ \\ ${ }^{a}$ Geosciences Azur, Quai de la Darse, BP 48, 06235 Villefranche sur mer., France \\ b Paleotropique, IRD, 32 Av. Henri Varagnat Bondy cedex F93143, France \\ ${ }^{\mathrm{c}}$ Département des Sciences de la Terre et de l'atmosphère, Université du Québec à Montréal, CP 8888, Succ. Centre-Ville, \\ Montréal, Canada H3C $3 P 8$ \\ ${ }^{\mathrm{d}}$ GEOTOP Université du Québec à Montréal, CP 8888, Succ. Centre-Ville, Montréal, Canada H3C 3P8
}

\begin{abstract}
Marine terrace sequences have been investigated along the Talara Arc, a 1000-km-long stretch of the coast of Ecuador and northern Peru, characterized by subduction with a concave plan-view. Seven areas were investigated, evidencing flights of up to seven marine terraces with elevations reaching up to $360 \mathrm{~m}$ above mean sea level (amsl). Dating of the terraces was made using the Infra Red Stimulated Luminescence (IRSL) technique on sands as old as MIS $9(\sim 330 \mathrm{ka}) .{ }^{14} \mathrm{C}$ and U-series dates were obtained from fossil shells for geochronological cross control. Mean uplift rates along the Talara Arc range from about 0.10 up to $0.50 \mathrm{~mm} /$ yr. The strongest uplift is observed in the Manta Peninsula of Ecuador in front of the subduction of the Carnegie Ridge. The uplift rate tends to slow down towards the northern and southern ends of the Talara Arc and then the transition toward the stable or subsiding coasts of central Peru and northern Ecuador and Colombia is sharp. The uplift appears to be homogeneous and related to 1) the map view curvature of the Arc, 2) the concave subduction pattern and 3) the Carnegie Ridge subduction.
\end{abstract}

Keywords: marine terrace; coastal uplift; concave subduction; ridge subduction; tablazo

\section{Introduction}

Vertical deformation along the Pacific coast of South America is apparently related to convergence between the subducting Nazca Plate and the South American

\footnotetext{
* Corresponding author. Present address: Key Laboratory of Marginal Sea Geology, South China Sea Institute of Oceanology and Guangzhou Institute of Geochemistry, Chinese Academy of Sciences, 164 West Xingang Road, 510301 Guangzhou, PR China. Tel.: +86 20 890205 92; fax: +862084458964.

E-mail address: pedoja_mathelin@yahoo.fr (K. Pedoja).
}

Plate. South American coastal segments showing coastal uplift are generally related to the subduction of aseismic ridges: the Nazca Ridge (Hsu, 1992; Macharé and Ortlieb, 1992), the Carnegie Ridge (Gutscher et al., 1999; Pedoja et al., 2001, 2003, in press), and the Cocos Ridge (Corrigan et al., 1990; Gardner et al., 1992). Between the areas affected by ridge subduction the coastal regions generally experience much slower uplift or even subsidence (Macharé and Ortlieb, 1992; Ortlieb et al., 1996). Emerged Pleistocene marine terraces located between $1.5^{\circ} \mathrm{N}$ and $6.5^{\circ} \mathrm{S}$ in Ecuador and 
North Peru (CERESIS, 1985) (Fig. 1) were documented by a series of local studies (e.g. Marchant, 1961; DeVries, 1984, 1986, 1988; Cantalamessa and Di Celma, 2004; Dumont et al., 2005; Pedoja et al., 2001, 2003, in press). Nevertheless, the regional and local tectonic mechanisms responsible for emersion of marine terrace are not yet fully understood. In particular, we need to determine the large-scale pattern of vertical deformation of the Talara Arc and to understand the relationship between these vertical motions and the subduction mechanisms. The uplifted coastal segment of the Talara Arc ends sharply to the north and south. To the south, in north-central Peru, a 900-km-long straight coastal segment between $6.5^{\circ} \mathrm{S}$ and $14^{\circ} \mathrm{S}$ has been stable or slightly subsiding since Pliocene time (Macharé and Ortlieb, 1992; Ortlieb et al., 1996). To the north, along a $400 \mathrm{~km}$ long coastal stretch from Esmeraldas (North Ecuador) to Buenaventura (Colombia), subsidence

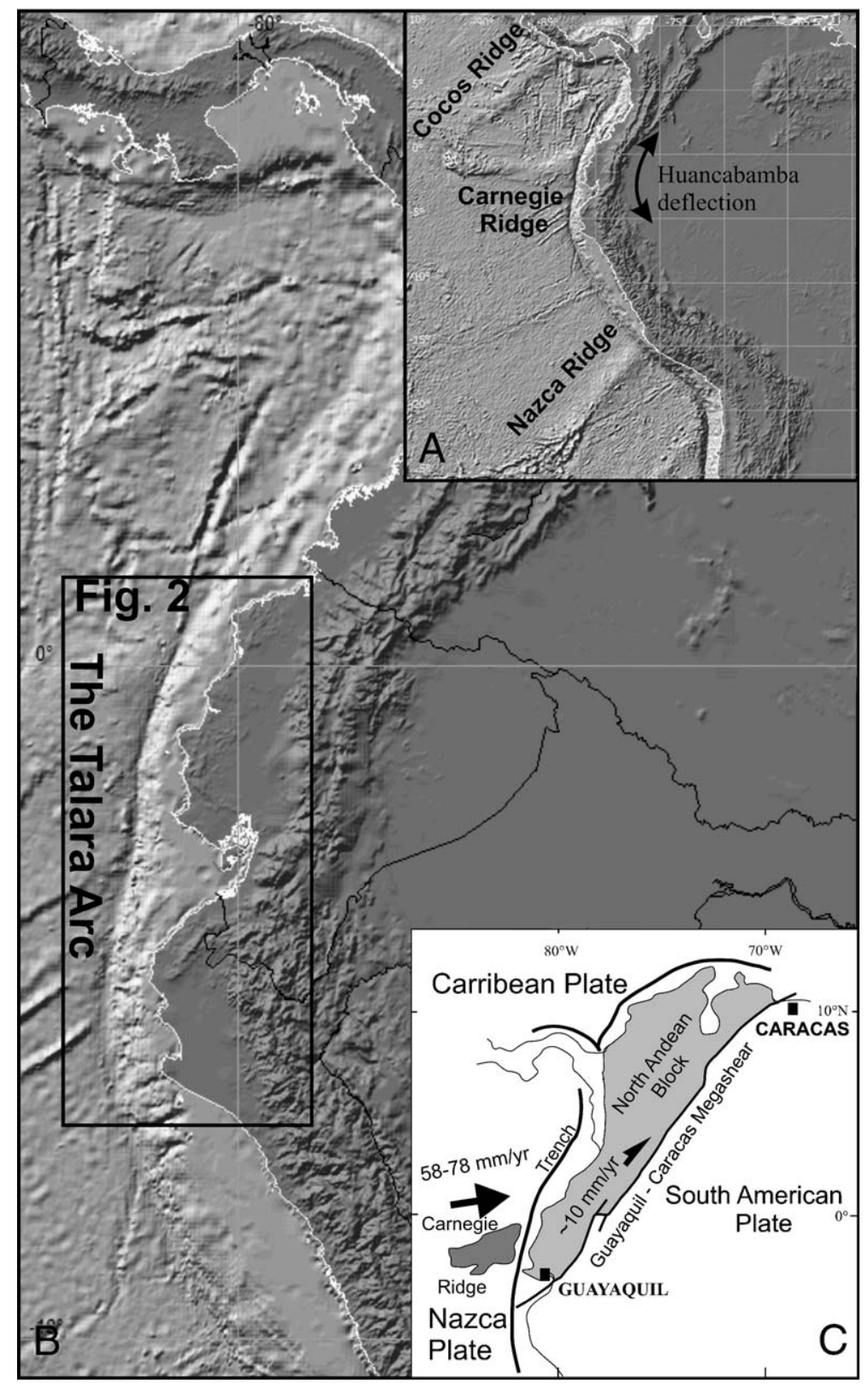

Fig. 1. The Talara Arc. (A) Location in South America. (B) Digital Elevation Model (DEM) of the area (C) Schematic structural scheme showing plate interaction. 
prevailed during the Quaternary (CERESIS, 1985; Deniaud, 2000). The aim of this paper is to contribute to the understanding of the geometrical pattern of vertical motions, which affect the long coastal segment encompassing northern Peru and Ecuador.

\section{Geodynamical and geological settings}

In this paper, the "Talara Arc" is defined as the $1000-\mathrm{km}$-long arc structure bordered by the concave subduction zone to the west and the base of the Andes to the east, including the continental shelf and the coastal margin. In any case, the word arc in this paper refers to a geometry and is definitively not related to the notion of fore-arc. The central part of the Talara Arc is bordered on the Andean side by the Huancabamba (or Cajamarca) Deflection (Fig. 1A) (for example Ganser, 1973; Roperch et al., 1987; Mourier et al., 1998). The changing direction of the Pacific side of the South American plate border is accompanied by significant variations in the width of the coastal margin and the Andean range. South of the Talara Arc, the Andean Range is high and wide

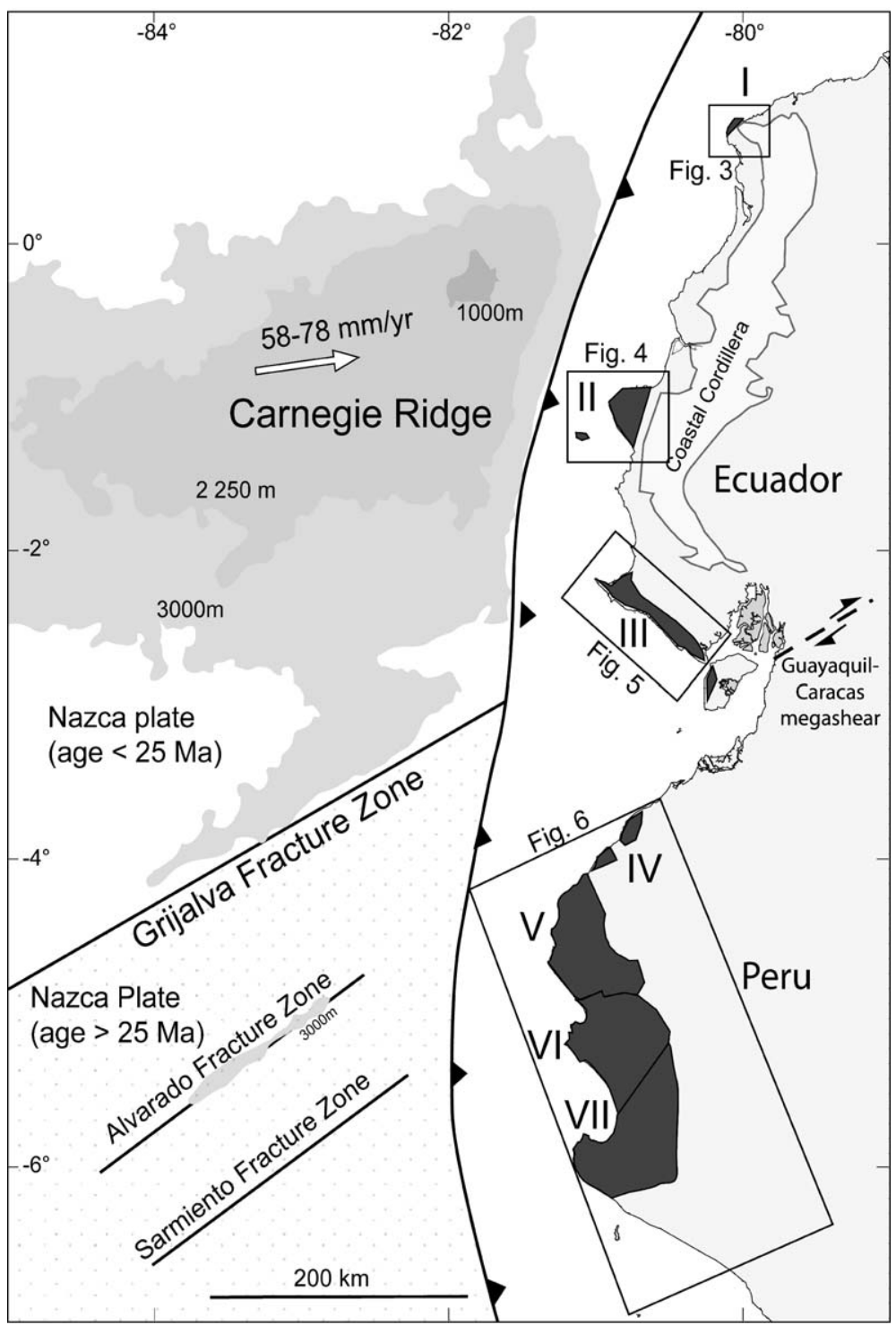

Fig. 2. Geodynamical context and marine terraces sequences on the Talara Arc. Ecuador: I Northern coast: Galera Point, II Central Coast: Manta Peninsula, La Plata Island. III Gulf of Guayaquil: Santa Elena Peninsula, Puna Island. Peru: IV Cancas, V Mancora: Los Organos, Lobitos, Talara, VI Paita Peninsula, VII Illescas Peninsula and paleo-bay of Bayovar. 
(Sloss, 1994; Watts et al., 1995), and the coastal margin is narrow or nearly lacking (Sloss, 1994) (Fig. 1A). In the Talara Arc region, the Andean range is relatively narrow and low, ending in several divided low ranges in northern Colombia (Sloss, 1994), and the coastal margin is wide, reaching $160 \mathrm{~km}$ in Central Ecuador. These continentscale morphologic and structural relationships give evidence of both long-lasting orogenic processes and short-term structural evolution along the subduction zone. The Nazca Plate subducts beneath the South American Plate $\left(\mathrm{N} 80^{\circ} \mathrm{E}\right.$ trend) at a rate of $58-78 \mathrm{~mm} /$ $\mathrm{yr}^{-1}$ (De Mets et al., 1989; Trenkamp et al., 2002). This trend defines oblique subduction to the north and south of the Talara Arc: less than $20^{\circ}$ to the south (northern Peru) it increases up to $50^{\circ}$ to the north (Northern Ecuador) (Ego et al., 1996). The oblique subduction is related to the north-eastward motion of the North Andean block along the Guayaquil Caracas Megashear at a rate of 7-10 mm/yr (Kellogg and Vega, 1995; Ego et al., 1996), and the subsequent opening of the Gulf of Guayaquil (Deniaud et al., 1999). The main structures of the Nazca plate in front of the Talara Arc are the Carnegie Ridge and the Grijalva fracture zone (GFZ, Fig. 2). The Carnegie Ridge, a $280 \mathrm{~km}$ large and $2000 \mathrm{~m}$ high oceanic plateau, enters the trench between $\sim 1^{\circ} \mathrm{N}$ and $\sim 2^{\circ} \mathrm{S}$ and is lifting it by $1500 \mathrm{~m}$ relative to the Peruvian trench to the south. The age of initiation of the subduction of the Carnegie ridge is debated, and may have begun as soon as the late Miocene (Daly, 1989; Gutscher et al., 1999) or in the Late Pliocene (Lonsdale, 1978; Pedoja et al., 2001, 2003). The Grijalva Fracture Zone (GFZ), which trends NE-SW with a 700-m, southeast-looking scarp, enters the subduction zone in front of the Gulf of Guayaquil. North of the GFZ, the oceanic crust is younger than $25 \mathrm{Ma}$, and older than $35 \mathrm{Ma}$ to the south (Daly, 1989) (Fig. 2). The subducting slab presents a normal slope north of the GFZ (Guillier et al., 2001), and a flat geometry to the south (Gutscher et al., 1999).

The north Peruvian and Ecuadorian Andes were formed by successive block accretions during the Mesozoic (Mourier et al., 1998) and the beginning of the Cenozoic (Feininger, 1980; Jaillard et al., 1995). The arc shape results from multi-phased compressional events that operated under a non-rotational mechanism during the Paleocene-Eocene, followed by post-Oligocene rotation of $25^{\circ}$ clockwise north of the deflection and $20^{\circ}$ counter clockwise south of it (for example Mitouard et al., 1990; Mitouard et al., 1992). During the Cenozoic, shallow coastal basins registered subsidence and accumulated marine deposits during episodes of fast conver- gence (up to $200 \mathrm{~mm} / \mathrm{yr}$ between 48 and $37 \mathrm{Ma}$ ), and emersion of continental deposits during a slow convergence regime (44 mm/yr between 37 and $20 \mathrm{Ma}$ ) (Shepherd and Moberly, 1981; Daly, 1989; Deniaud, 2000). Pliocene and Plio-Quaternary formations discordantly overlay these basins and are represented by shallow marine deposits (Canoa Fm. in Manta, Tablazo Fm. in Santa Elena and Puna, Taime Fm. in northern Peru). Pleistocene marine terraces discordantly cover all the sequences. However, the marine terrace deposits frequently include shallow to intertidal facies very similar to those of the Pliocene deposits, thus the boundary between Pliocene and Pleistocene deposits is hard to define where both units are present.

On the Talara Arc - and especially on the Peruvian part of the arc - the landscape is characterized by the widespread development of wide, compound, gently sloping marine terraces traditionally called "Tablazos" (Bosworth, 1922; DeVries, 1984, 1988). Their development is attributed 1) to the fact that these surfaces frequently have been softened by aeolian erosion and deposits and 2) to the combination and re-occupation of platforms during successive high stands, forming compound marine terraces without marked shoreline angles, according to conditions analysed by Kelsey and Bockheim (1994), and Trenhaile (2001, 2002).

\section{Study methods}

An emerged marine terrace is a paleo-shore-platform covered or not by beach and/or shallow marine deposits, formed during a sea-level highstand. A sequence of uplifted Pleistocene marine terraces corresponds to the geologic and geomorphic records of repeated glacioeustatic sea-level highstands superimposed on a rising coastline (Bull, 1985; Ota, 1986). Quaternary highstands representing interglacial stages are correlated with marine isotopic stages and substages (MIS and MISS) from oxygen-isotope stratigraphy, with assignment of odd numbers for MIS (5, 7, 9...). Some Interglacial stages include several sub-stages (MISS) recording minor eustatic oscillations related to different sea-level highstands that are referred by a suffix (MISS 5a for example). The last interglacial maximum (LIM) corresponds to the MISS $5 \mathrm{e}$. The equation $(E-e) / A$ gives the net uplift rate of the considered marine terrace, where $(E-e)$ represents the total vertical displacement of the shoreline angle. It corresponds to the present shoreline altitude $(E)$ corrected for the eustatic level $(e)$ of the considered MIS relative to the present one. The term " $A$ " corresponds to the age of the MIS considered for the carving of the shoreline angle. Determination on 
eustatic level and the age of respective MIS are taken from Zazo (1999) (see Table 2 for precise value). In this study, all altitudes are given in meters above mean sea level (amsl) with reference to the nearest tide gauge. The marine terraces are named T1, T2, T3... from the lowest to the highest. Fieldwork was conducted from 1987 to 2002.

Chronostratigraphic interpretation of the marine terrace data is partly based upon results from three dating methods: Infrared Stimulated Luminescence (IRSL), U/Th decay and ${ }^{14} \mathrm{C}$.

Luminescence dating (Aitken, 1985, 1998), applied recently to shallow marine sands from raised terraces (Wood, 1994), has been used on marine terrace deposits (feldspars in the sand) from the Talara Arc. The equivalent dose (De) was determined using a modified version of the Single Aliquot Regeneration (Murray and Wintle, 2000) of feldspar, as reported by Lamothe and Auclair (1999). Anomalous fading of feldspar luminescence was corrected using the equation recently proposed by Huntley and Lamothe (2001). The ages quoted in the paper are those derived from the mean of 16 aliquots, measured $1 \mathrm{~h}$ after irradiation. The fading parameter, $g$, was evaluated over several days for every aliquot, and the mean $g$ value from the distribution of the 16 aliquots was used to correct for anomalous fading (Auclair et al., 2002). There are two limitations here. First, the correction developed by Huntley and Lamothe (2001) is shown to be only reliable for young sediment samples, i.e. those for which the luminescence signal is in the linear part of the dose response curve. The natural luminescence of all the samples is slightly beyond linearity so that the corrected IRSL age still should be considered as younger than the depositional age. It is also assumed that all the grains in the sediment samples were fully bleached before burial. It seems that this assumption is reasonable, given the coherence of the luminescence data set.

The uranium decay method has been applied since the 1960s to shells from marine terraces (Herbert-Veeh, 1966), but the method has been reviewed more recently (McLaren and Rowe, 1996). In this study, the U/Th data do not contradict the stratigraphy and are concordant with the IRSL ages. The reproducibility of the analytical process was tested using a replicate measurement of a coral from Timor Island (last interglacial Maximum MIS $5 \mathrm{e}$ ), and a uraninite standard. The error is routinely lower than $\pm 0.5 \%$. All errors are reported as $2 \sigma$ of the mean.

Dating by ${ }^{14} \mathrm{C}$ was performed on seashells from a Peruvian marine terrace that was previously attributed to the Holocene (Macharé and Ortlieb, 1994). However our ${ }^{14} \mathrm{C}$ dating processed by the Beta Analytic Company (Miami, USA) is close to the limit of the method, and provides only a minimum age.

\section{Marine terraces of the Talara Arc}

Most of the Talara Arc presents a rocky coast with peninsulas and more or less prominent capes like the Manta, Paita and Illescas areas spaced 50-150 km apart (Fig. 2). Since $\sim 1.5 \mathrm{Ma} \mathrm{BP}$, the total net regression due to the main uplift of the coast reaches $20000 \mathrm{~km}^{2}$. Coastal retreats generally are on the order of $20-30 \mathrm{~km}$ except in northern Peru, where they reach $70 \mathrm{~km}$. We describe herein the main sequences of terraces from north to south, in Ecuador and northern Peru.

\subsection{Ecuador}

We observed, from Point Galera (northern coast of Ecuador) to the Gulf of Guayaquil to the south, marine terraces in three main areas (Fig. 2): 1) The Point Galera near Esmeraldas, 2) the Manta Peninsula, and 3) along the northern margin of the Gulf of Guayaquil (Santa Elena Peninsula).

\subsubsection{Point Galera (sequence I)}

4.1.1.1. Description. On the Galera Point, three marine terraces T1, T2 and T3, carved in the Onzole Formation (Upper Miocene-Lower Pliocene) are locally covered by marine sediments $2-3 \mathrm{~m}$ thick. On the eastern side of Point Galera the terraces cover an area 3 to $5 \mathrm{~km}$ wide and 15 to $20 \mathrm{~km}$ long, limited to the south by the NE-SW trending Galera Fault (Fig. 3) (DGGM, 1980). The maximum altitudes of marine terraces T1, T2 and $\mathrm{T} 3$ are at $45 \pm 2,61 \pm 3$ and $101 \pm 3 \mathrm{~m}$ (Figs. 3 and 7). The NE-SW trending Cumilinche fault (DGGM, 1980) displaced T1 and T2 (Fig. 3) with respective offsets of 10 and $20 \mathrm{~m}$ and therefore a minor relative uplift of the southeastern side of the fault. Recent motion of the Cumilinche fault is consistent with features observed on aerial photos and radar images. Marine terrace T3 lacks suitable sediments to be sampled for dating but samples C25 and C26 provided geochronological data for terraces $\mathrm{T} 1$ and T2, respectively (Fig. 3).

\subsubsection{Tentative chronostratigraphic measurements and uplift rates. Samples C25 (T1) and C26 (T2) provided IRSL corrected ages of $98 \pm 23$ and $220 \pm 42 \mathrm{ka}$, respectively (Table 1 ). We propose correlating the $\mathrm{T} 1$ shoreline angle with MISS 5e (130 ka), even if the deposit sampled in C25 suggests a MISS 5c age (105 ka).}



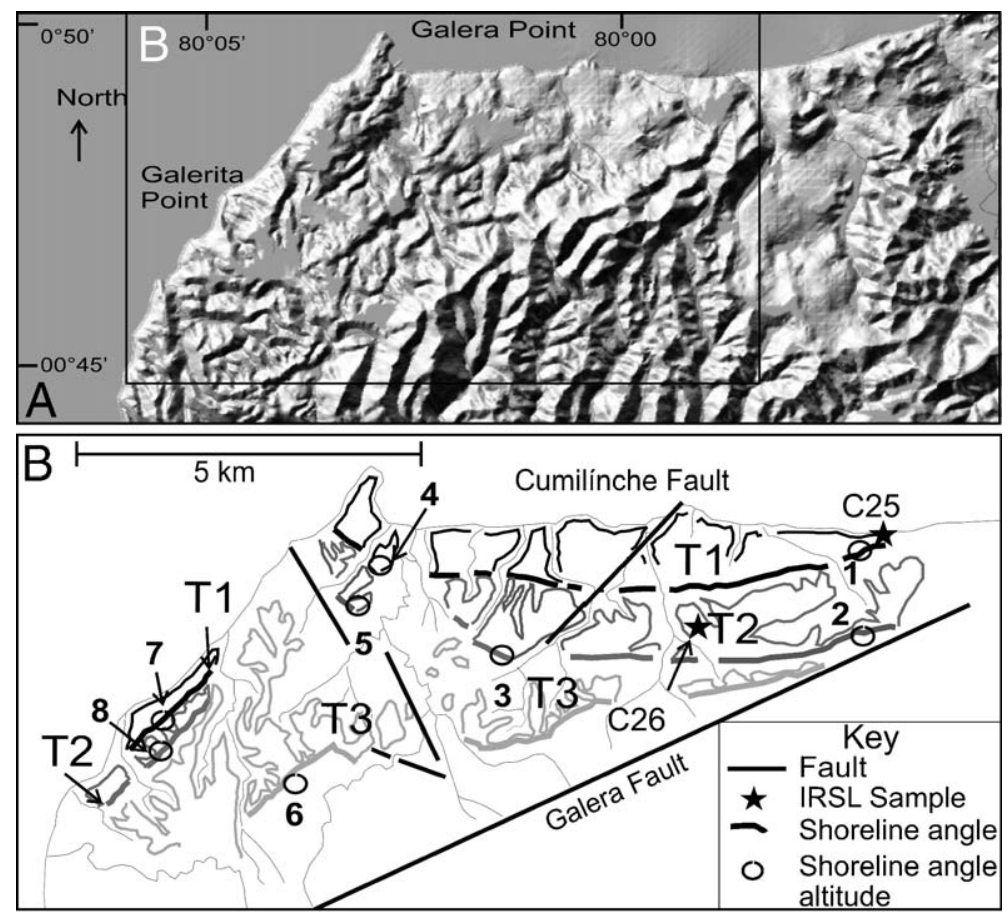

Fig. 3. Sequence I at Point Galera. (A) DEM of the studied area (B) Marine terraces on Galera Point. T1: 1: 20 $\pm 1 \mathrm{~m}, 4: 46 \pm 2 \mathrm{~m}, 7: 43 \pm 4 \mathrm{~m}$; T2: 2: 53 $\pm 3 \mathrm{~m}, 3: 65 \pm 3 \mathrm{~m}, 5: 61 \pm 3 \mathrm{~m}, 8: 64 \pm 4 \mathrm{~m}$; T3: 6: $101 \pm 3 \mathrm{~m}$.

There is no morphologic evidence for MIS 5a and/or 5c

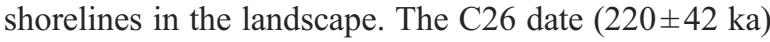
leads us to propose a correlation with MIS 7 (220 ka) for T2 (Fig. 8). Calculated uplift rates for T1 and T2 are $0.33 \mathrm{~mm} / \mathrm{yr}$ (Table 2) west of the Cumilinche fault. If a constant uplift rate of $0.30 \mathrm{~mm} / \mathrm{yr}$ is extrapolated back in time, the $101 \pm 5 \mathrm{~m}$ elevation of T3 would suggest that the terrace was formed between 320 and $350 \mathrm{ka}$, i.e. during MIS $9(330 \mathrm{ka})$.

\subsubsection{Manta Peninsula and La Plata Island (sequences IIa-IIc)}

4.1.2.1. Description. Recent study (Cantalamessa and Di Celma, 2004; Pedoja et al., in press) provides overview of the marine terrace flights of central Ecuador (i.e. Manta Peninsula and La Plata Island). Cantalamessa and Di Celma (2004) propose a chronostratigraphical interpretation for La Plata Island.

Table 1

IRSL analysis and IRSL age of the feldspar from marine terraces deposit along the Talara Arc

\begin{tabular}{|c|c|c|c|c|c|c|c|c|c|c|c|}
\hline \multirow[t]{3}{*}{ Sequence and sample name } & & \multirow{2}{*}{\multicolumn{2}{|c|}{$\begin{array}{l}\begin{array}{l}\text { Equivalent } \\
\text { dose }\end{array} \\
(\mathrm{Gy})\end{array}$}} & \multirow{2}{*}{\multicolumn{2}{|c|}{$\begin{array}{l}\text { Annual dose } \\
(\mathrm{Gy} / \mathrm{ka})\end{array}$}} & \multicolumn{4}{|c|}{ Ages IRSL } & \multirow[t]{3}{*}{$\begin{array}{l}\text { Terrace } \\
\text { number }\end{array}$} & \multirow{3}{*}{$\begin{array}{l}\text { MIS or MISS } \\
\text { assigned to } \\
\text { the terrace }\end{array}$} \\
\hline & & & & & & \multicolumn{2}{|c|}{ Measured } & \multicolumn{2}{|c|}{ Corrected } & & \\
\hline & & & Err & & Err & & Err & & Err & & \\
\hline \multirow[t]{2}{*}{ I Galera Point } & $\mathrm{C} 25$ & 66 & 13 & 1.04 & 0.08 & 63 & 13 & 98 & 23 & $\mathrm{~T} 1$ & $5 \mathrm{e}$ \\
\hline & $\mathrm{C} 26$ & 182 & 49 & 1.29 & 0.10 & 141 & 40 & 220 & 42 & $\mathrm{~T} 2$ & 7 \\
\hline \multirow[t]{6}{*}{ IIa and IIB Manta Peninsula } & $\mathrm{C} 5$ & 76 & 11 & 1.36 & 0.10 & 56 & 8 & 76 & 18 & $\mathrm{~T} 1$ & $5 \mathrm{e}$ \\
\hline & $\mathrm{C} 7$ & 230 & 26 & 1.45 & 0.13 & 158 & 15 & 232 & 35 & $\mathrm{~T} 2$ & 7 \\
\hline & $\mathrm{C} 8$ & 190 & 9 & 1.13 & 0.11 & 168 & 17 & 272 & 38 & $\mathrm{~T} 3$ & 9 \\
\hline & $\mathrm{C} 12$ & 169 & 9 & 1.29 & 0.12 & 131 & 20 & 212 & 3 & $\mathrm{~T} 2$ & 7 \\
\hline & $\mathrm{C} 13$ & 195 & 30 & 1.35 & 0.12 & 138 & 15 & 203 & 32 & $\mathrm{~T} 2$ & 7 \\
\hline & $\mathrm{C} 23$ & 112 & 22 & 1.33 & 0.12 & 84 & 17 & 115 & 23 & $\mathrm{~T} 1$ & $5 \mathrm{e}$ \\
\hline \multirow[t]{4}{*}{ VIIa Bayovar embayment } & NP18 & 206 & 13 & 2.80 & 0.16 & 73 & 6 & 111 & 6 & $\mathrm{~T} 2$ & $5 e$ \\
\hline & NP20-1 & 331 & 32 & 4.53 & 0.32 & 73 & 9 & 107 & 9 & T3 & 7 \\
\hline & NP20-2 & 331 & 32 & 3.68 & 0.20 & 90 & 10 & 133 & 10 & $\mathrm{~T} 3$ & 7 \\
\hline & NP20-3 & 331 & 32 & 2.86 & 0.15 & 116 & 13 & 172 & 13 & $\mathrm{~T} 3$ & 7 \\
\hline
\end{tabular}


Table 2

Determination of uplift rates from dated marine terrace of the Talara Arc

\begin{tabular}{|c|c|c|c|c|c|c|c|}
\hline \multicolumn{3}{|c|}{ Sequence and terrace number } & \multirow{2}{*}{$\begin{array}{l}\text { Shoreline angle } \\
\text { altitude }(\mathrm{m})\end{array}$} & \multirow{2}{*}{$\begin{array}{l}\text { Assumed age } \\
\text { for MIS or MISS } \\
120(5 \mathrm{e})\end{array}$} & \multirow{2}{*}{$\begin{array}{l}\begin{array}{l}\text { Eustatic } \\
\text { level }(\mathrm{m})\end{array} \\
5 \pm 1\end{array}$} & \multirow{2}{*}{$\begin{array}{l}\text { Net uplift (m) } \\
41 \pm 3\end{array}$} & \multirow{2}{*}{$\begin{array}{l}\begin{array}{l}\text { Mean uplift rate } \\
(\mathrm{mm} / \mathrm{yr} \text { or } \mathrm{m} / \mathrm{ka})\end{array} \\
0.34 \pm 0.02\end{array}$} \\
\hline I Galera & & $\mathrm{T} 1$ & & & & & \\
\hline & & $\mathrm{T} 2$ & $65 \pm 3$ & $220(7)$ & $-1 \pm 1$ & $66 \pm 4$ & $0.30 \pm 0.02$ \\
\hline \multirow[t]{7}{*}{ II Manta and La Plata } & \multirow[t]{3}{*}{ IIa } & $\mathrm{T} 1$ & $43 \pm 2$ & $120(5 \mathrm{e})$ & $5 \pm 1$ & $38 \pm 3$ & $0.31 \pm 0.02$ \\
\hline & & $\mathrm{T} 2$ & $77 \pm 3$ & $220(7)$ & $-1 \pm 1$ & $78 \pm 4$ & $0.35 \pm 0.01$ \\
\hline & & $\mathrm{T} 3$ & $130 \pm 10$ & $330(9)$ & $1 \pm 1$ & $129 \pm 11$ & $0.39 \pm 0.03$ \\
\hline & \multirow[t]{3}{*}{$\mathrm{IIb}$} & $\mathrm{T} 1$ & $57 \pm 2$ & $120(5 \mathrm{e})$ & $5 \pm 1$ & $51 \pm 3$ & $0.42 \pm 0.02$ \\
\hline & & $\mathrm{T} 2$ & $110 \pm 10$ & $220(7)$ & $-1 \pm 1$ & $111 \pm 11$ & $0.50 \pm 0.05$ \\
\hline & & $\mathrm{T} 3$ & $170 \pm 10$ & $330(9)$ & $1 \pm 1$ & $169 \pm 11$ & $0.51 \pm 0.03$ \\
\hline & \multirow[t]{3}{*}{ IIc } & $\mathrm{T} 1$ & $43 \pm 2$ & $120(5 \mathrm{e})$ & $5 \pm 1$ & $38 \pm 3$ & $0.31 \pm 0.02$ \\
\hline III Santa Elena & & $\mathrm{T} 1$ & $18 \pm 2$ & $120(5 \mathrm{e})$ & $5 \pm 1$ & $13 \pm 3$ & $0.10 \pm 0.02$ \\
\hline IVa Cancas & & $\mathrm{T} 1$ & $30 \pm 5$ & $120(5 \mathrm{e})$ & $5 \pm 1$ & $25 \pm 6$ & $0.20 \pm 0.05$ \\
\hline \multirow[t]{4}{*}{ V } & \multirow[t]{2}{*}{$\mathrm{Va}$} & $\mathrm{T} 1$ & $31 \pm 1$ & $120(5 \mathrm{e})$ & $5 \pm 1$ & $26 \pm 2$ & $0.21 \pm 0.01$ \\
\hline & & $\mathrm{T} 2$ & $60 \pm 10$ & $220(7)$ & $-1 \pm 1$ & $61 \pm 11$ & $0.27 \pm 0.05$ \\
\hline & \multirow[t]{2}{*}{$\mathrm{Vb}$} & $\mathrm{T} 1$ & $26 \pm 2$ & $120(5 \mathrm{e})$ & $5 \pm 1$ & $21 \pm 3$ & $0.17 \pm 0.02$ \\
\hline & & $\mathrm{T} 2$ & $60 \pm 10$ & $220(7)$ & $-1 \pm 1$ & $61 \pm 11$ & $0.27 \pm 0.05$ \\
\hline \multirow{2}{*}{\multicolumn{2}{|c|}{ VI Paita }} & $\mathrm{T} 1$ & $89 \pm 2$ & $330(9)$ & $1 \pm 1$ & $88 \pm 3$ & $0.26 \pm 0.01$ \\
\hline & & $\mathrm{T} 2$ & $115 \pm 3$ & $400(11)$ & $6 \pm 1$ & $109 \pm 4$ & $0.27 \pm 0.01$ \\
\hline \multirow{2}{*}{\multicolumn{2}{|c|}{ VII Bayovar }} & $\mathrm{T} 2$ & $18 \pm 3$ & $120(5 \mathrm{e})$ & $5 \pm 1$ & $15 \pm 6$ & $0.12 \pm 0.05$ \\
\hline & & $\mathrm{T} 3$ & $33 \pm 1$ & $220(7)$ & $-1 \pm 1$ & $34 \pm 2$ & $0.15 \pm 0.01$ \\
\hline
\end{tabular}

In the Peninsula, their observations differ somehow from those of Pedoja et al. (in press) and from those presented in this study, observations that will be discussed later.

Marine terraces are relatively well preserved on the Manta Peninsula (Fig. 4), the oldest one being found at a maximal altitude of $360 \pm 10 \mathrm{~m}$ (sequence IIb, Fig. 7). We observed flights of five major marine terraces on the peninsula (sequences IIa and IIb, Fig. 7) whereas Cantalamessa and Di Celma (2004) only describe three marine terraces. The geometric disposition of the two highest terraces (T4 and T5) shows that the Manta Peninsula was originally an island before it was connected to the continent, during the time of formation of marine terrace T3. Located $25 \mathrm{~km}$ southwest off the Manta Peninsula (Fig. 4), La Plata Island presents a sequence of four marine terraces cut in Cretaceous basaltic basement rocks, with a thin discontinuous sedimentary cover. A description of marine terraces from the Manta Peninsula and La Plata Island was given by Cantalamessa and Di Celma (2004), Pedoja et al., (2003, in press), and only the main results will be summarized here.

On the northern side of the Manta Peninsula (sequence IIa, Fig. 7), the shoreline angles of the T1, T2, T3, T4 and T5 terraces were found at maximum altitudes of $43 \pm 2,77 \pm 3,130 \pm 10,203 \pm 10$, and 300 $\pm 10 \mathrm{~m}$, respectively. On the southern side of the Manta Peninsula (sequence IIb, Fig. 7), the terraces T1, T2, T3, $\mathrm{T} 4$ and $\mathrm{T} 5$ are characterized by the following elevations
$57 \pm 2,110 \pm 10,170 \pm 10,240 \pm 10,360 \pm 10 \mathrm{~m}$, respectively. The differences in elevation for the same marine terrace north and south of the Manta Peninsula (for example T1 at $57 \pm 2 \mathrm{~m}$ to the south and $43 \pm 2 \mathrm{~m}$ to the north) are attributed to the movements along the Montecristi Fault (DGGM, 1970), an old transcurrent fault reactivated as a normal fault during the Pleistocene (Pedoja et al., 2003). Deposits of the three lower terraces of sequence IIa and of the first terrace of sequence IIb were sampled for geochronological analyses (Fig. 4 C). In sequence IIa, IRSL sample C5 was taken from a T1 deposit far from the T1 shoreline. Samples C7, C12, $\mathrm{C} 13$ were taken in $\mathrm{T} 2$ deposits, and $\mathrm{C} 8$ was taken from T3 deposits. C23 was sampled in T1 of sequence IIb. Fauna from deposits of T1 and T2 (sequence IIa) were collected for U/Th measurements (samples Manta 6 and Manta 10, respectively, on Fig. 4 C).

On La Plata Island, the shoreline angles T1, T2 and $\mathrm{T} 3$ are at the following altitudes: $47 \pm 2,73 \pm 3$, and 145 $\pm 5 \mathrm{~m}$, respectively. The T4 marine terrace is at $160 \mathrm{~m}$. As the platform makes the top of the hill no shoreline angle is observed, and we estimate a paleo sea level at $170 \pm 10 \mathrm{~m}$. Shells from T1 were collected for U/Th dating (sample Costa 4, Fig. 4D).

\subsubsection{Tentative chronostratigraphic measurements} and uplift rates. On the northern part of the peninsula (Sequence IIa, Figs. 4 and 7), dates were obtained using IRSL and U/Th. Samples taken from T1 deposits (C5 and Manta 6) have a corrected IRSL age of $76 \pm 16 \mathrm{ka}$ 


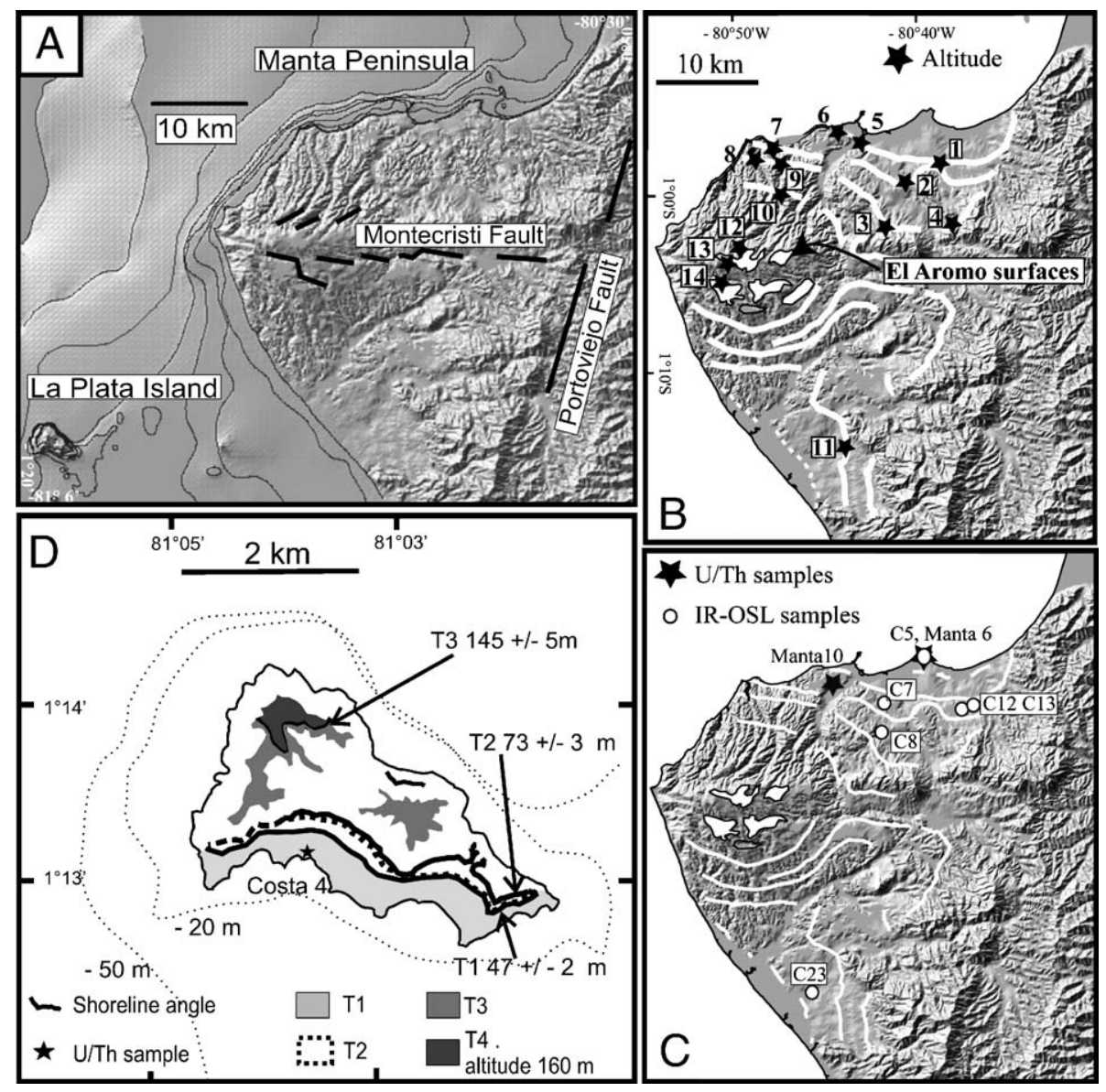

Fig. 4. Sequence II a, b and $\mathrm{c}$ in the central coast of Ecuador. (A) DEM of the studied area (B) Marine terraces on the Manta Peninsula (C) Location of the U/Th and IRSL samples on the Manta Peninsula (D) Marine terraces on La Plata Island.

(C5, Table 1) and $\mathrm{U} / \mathrm{Th}$ age of $85 \pm 1.2 \mathrm{ka}$ (Table 3). It is assumed that the $\mathrm{T} 1$ shoreline angle was formed during MIS 5. Samples C7, C12, C13, taken from T2, yielded IRSL ages of $232 \pm 35 ; 212 \pm 3,203 \pm 32$, while for Manta 10, the $\mathrm{U} / \mathrm{Th}$ sample provided a minimum age of $187 \pm 3.7 \mathrm{ka}$. We propose correlating the T2 shoreline angle with MIS 7. Sample C8 taken from a T3 deposit has an IRSL corrected age of $272 \pm 38 \mathrm{ka}$, which led us to correlate the T3 shoreline angle with MIS 9 (330 ka).
On the southern part of the Manta Peninsula, C23 sampled from a T1 deposit has an IRSL corrected age of $115 \pm 23$ ka compatible, with a MISS 5e age. By stratigraphical correlation with the northern sequence, we propose correlating the T3 shoreline angles with MIS 7 and 9, respectively. On La Plata Island (sequence IIc, Figs. 4 and 7), Costa 4 has a minimum U/Th age of $104 \pm 1.8 \mathrm{ka}$, suggesting that the T1 shoreline was formed during MIS 5, and probably MISS 5e.

Table 3

$\mathrm{U} / \mathrm{Th}$ analysis and $\mathrm{U} / \mathrm{Th}$ results on seashells from marine terraces deposits of the Talara Arc

\begin{tabular}{|c|c|c|c|c|c|c|c|c|c|}
\hline Sample & Const. ${ }^{230} \mathrm{Th}$ & Const. ${ }^{234} \mathrm{U}$ & ${ }^{230} \mathrm{Th} /{ }^{234} \mathrm{U}$ & $\pm{ }^{230} \mathrm{Th} /{ }^{234} \mathrm{U}$ & ${ }^{234} \mathrm{U} /{ }^{238} \mathrm{U}$ & $\pm^{234} \mathrm{U} /{ }^{238} \mathrm{U}$ & Age (ka) & + & - \\
\hline Manta-6 & 0.009195 & 0.002835 & 0.834 & 0.0054 & 1.1168 & 0.009 & 85.060 & 1.221 & 1.202 \\
\hline Manta-10 & 0.009195 & 0.002835 & 0.549 & 0.0048 & 1.0664 & 0.005 & 187.967 & 3.722 & 3.577 \\
\hline Costa 4 & 0.009195 & 0.002835 & 0.6565 & 0.0073 & 1.9205 & 0.0145 & 104.146 & 1.872 & 1.840 \\
\hline Costa-1 & 0.009195 & 0.002835 & 0.74530 & 0.01120 & 1.3365 & 0.0256 & 136.204 & 4.536 & 4.298 \\
\hline Costa-1bis & 0.009195 & 0.002835 & 0.66480 & 0.00590 & 1.3062 & 0.0118 & 111.974 & 1.854 & 1.814 \\
\hline El Morro & 0.009195 & 0.002835 & 0.60790 & 0.00990 & 1.1907 & 0.0228 & 98.443 & 2.906 & 2.796 \\
\hline El Morrobis & 0.009195 & 0.002835 & 0.59680 & 0.00100 & 1.2100 & 0.0016 & 95.393 & 0.268 & 0.268 \\
\hline
\end{tabular}


On sequence IIa, uplift rates range from $0.30 \pm 0.03$ (MISS 5e) to $0.39 \pm 0.03 \mathrm{~mm} / \mathrm{yr}$ (MIS9). On sequence $\mathrm{IIb}$, on the southern part of the peninsula, uplift rates range from $0.41 \pm 0.04$ (MISS 5e) to $0.51 \pm 0.03 \mathrm{~mm} / \mathrm{yr}$ (MIS 9). Owing to the error range, the differences in uplift rates are not considered significant. In this zone (southern part of the Manta Peninsula), Cantalamessa and Di Celma (2004) only described three marine terraces, sloping gently to the south.

On La Plata Island, the tentative correlation of $\mathrm{T} 1$ with MISS 5e suggests uplift rates of $0.30 \pm 0.04 \mathrm{~mm} / \mathrm{yr}$. These results agree with the $0.4 \mathrm{~mm} / \mathrm{yr}$ net uplift rate of Cantalamessa and Di Celma (2004) for the T1 shoreline (named Plata 3 in their Table 1). The difference derives from the fact that they estimated the $\mathrm{T} 1$ shoreline angle at $55 \pm 5 \mathrm{~m}$ (we found it to be at an elevation of $47 \pm 2 \mathrm{~m}$ ) and also from the age considered for MISS 5e (124 versus $120 \mathrm{ka}$ ). Their study suggests that T2 (also referred to as Plata-3, in their Table 1), T3 (Plata 2 of their study) and T4 (Plata 1 of their study) may be related to MIS 7, MIS 11 and MIS 13, respectively, and that the MIS 9 terrace is lacking on the island. With only one geochronological datum (sample Costa 3, Table 3), it is difficult to discuss their interpretation. On the Manta Peninsula, extrapolations of the Late Pleistocene rates from the Northern Manta Peninsula yielded ages from 650 to $710 \mathrm{ka}$ for T4 $(203 \pm 10 \mathrm{~m})$ and $\sim 1 \mathrm{Ma}$ for T5 $(300 \pm 10 \mathrm{~m})$.

\subsubsection{The north of the Gulf of Guayaquil (sequences III - -IIId)}

From the Santa Elena Peninsula to Puna Island, a straight rocky coast, backed by marine terraces (DGGM, $1974 ; 1975)$, is present on the northern flank of the graben constituted by the Gulf of Guayaquil (Deniaud et al., 1999). Marine terraces have been studied at the two ends of this coastal segment, at Point Salinas and on Puna Island (Dumont et al., 2005).

\subsubsection{Description. Previous geological studies} pointed out the presence of three marine terraces T1, T2 and T3 on the Santa Elena Peninsula (Hoffstetter, 1948; Marchant, 1961), and their extension eastward along the northern margin of the Gulf of Guayaquil to Puna Island (Bristow and Hoffstetter, 1977; Dumont et al., 2005).

This sequence of three marine terraces is observed along the coastal stretch of the Santa Elena peninsula and the altitudes of the same shorelines are similar over long distances. On the peninsula, La Cruz Fault and the Estancias hills separate the marine terraces from the Progresso Basin. Faults perpendicular to the shore
(Chanduy Fault on Fig. 5 for example) have not been active since terrace formation. Near Santa Elena (sequence IIIa, Fig. 7), T1, T2, T3 are observed at respective elevations of $15 \pm 5,35 \pm 10$ and $80 \pm 10 \mathrm{~m}$ (Fig. 5). North of the Peninsula, near Santa Elena, T1 is associated with marine deposits up to $2 \mathrm{~m}$ in thickness, and a shoreline angle at an elevation of $15 \pm 5 \mathrm{~m}$. Fauna has been collected in $\mathrm{T} 1$ in the southern part of the Santa Elena Peninsula (samples Costa 1 and 1 bis, El Morro and El Morro bis) (Fig. 5). The Santa Elena T2 terrace (Hoffstetter, 1948) presents a shoreline angle at $35 \pm 10$ $\mathrm{m}$ in the Santa Elena area (Fig. 7). Thick coarse grainstone constitutes the Santa Elena terrace deposit. The $\mathrm{T} 3$ terrace forms the culminating morphology of the area, at an elevation of $80 \pm 10 \mathrm{~m}$ in the Santa Elena area (Ballenita Hills). As for T2, no sediments suitable for dating were found.

On the Lighthouse Hill at Point La Puntilla in Salinas, the chert basement favoured conservation of a sequence of four marine terraces (sequence IIIb, Fig. 7). In fact, a sharp shore platform stands between the present sea level and the 15-20 m terrace (T1 of the rest of the Peninsula and Puna Island) (Santana et al., 2002). The T1, T2, T3, and T4 shorelines are at $2.5 \pm 0.5,18 \pm 2$, $48 \pm 2$ and $80 \pm 5 \mathrm{~m}$, respectively (Fig. 7). In this zone, $\mathrm{T} 2$ is the equivalent of terrace T1 (Muey terrace of Hoffstetter, 1948) in other parts of the peninsula (Fig. 5). Around the chert hills, the sedimentary cover of the terraces is scarce or lacking.

\subsubsection{Tentative chronostratigraphic measurements} and uplift rates. Measurements utilizing U/Th from T1 (Sequence IIIa, Fig. 7) in the northern part of the peninsula were made on the thick columella of a gastropod shell, Conus aff fergusoni (samples Costa 1 and Costa 1 bis, Fig. 5) yielding minimum ages of 111 and $136 \mathrm{ka}$. On the southern side of the Peninsula, U/Th measurements made on Anadara grandis (El Morro and El Morro bis, Fig. 5) provided U/Th ages of 98 and 95 ka (Table 3). Based on U/Th dating despite its uncertainty and the possibility that they may be minimum age and comparison with the chronostratigraphic interpretation of Dumont et al. (2005) for Puna Island, we attribute the T1 marine terrace to MISS 5e. Its homologue, T2 of sequence IIb, Fig. 7) is tentatively attributed to MIS 5e by morphologic correlation with both sequences on the peninsula and on Puna Island. In this case, we propose that the low T1 terrace was formed during a subsequent sea level highstand within the last interglacial (MIS 5 substage 5a or 5c).

Uplift rates, deduced from the $\mathrm{T} 1$ altitude of the sequence IIIa and IIId or T2 altitude in sequence IIIb 


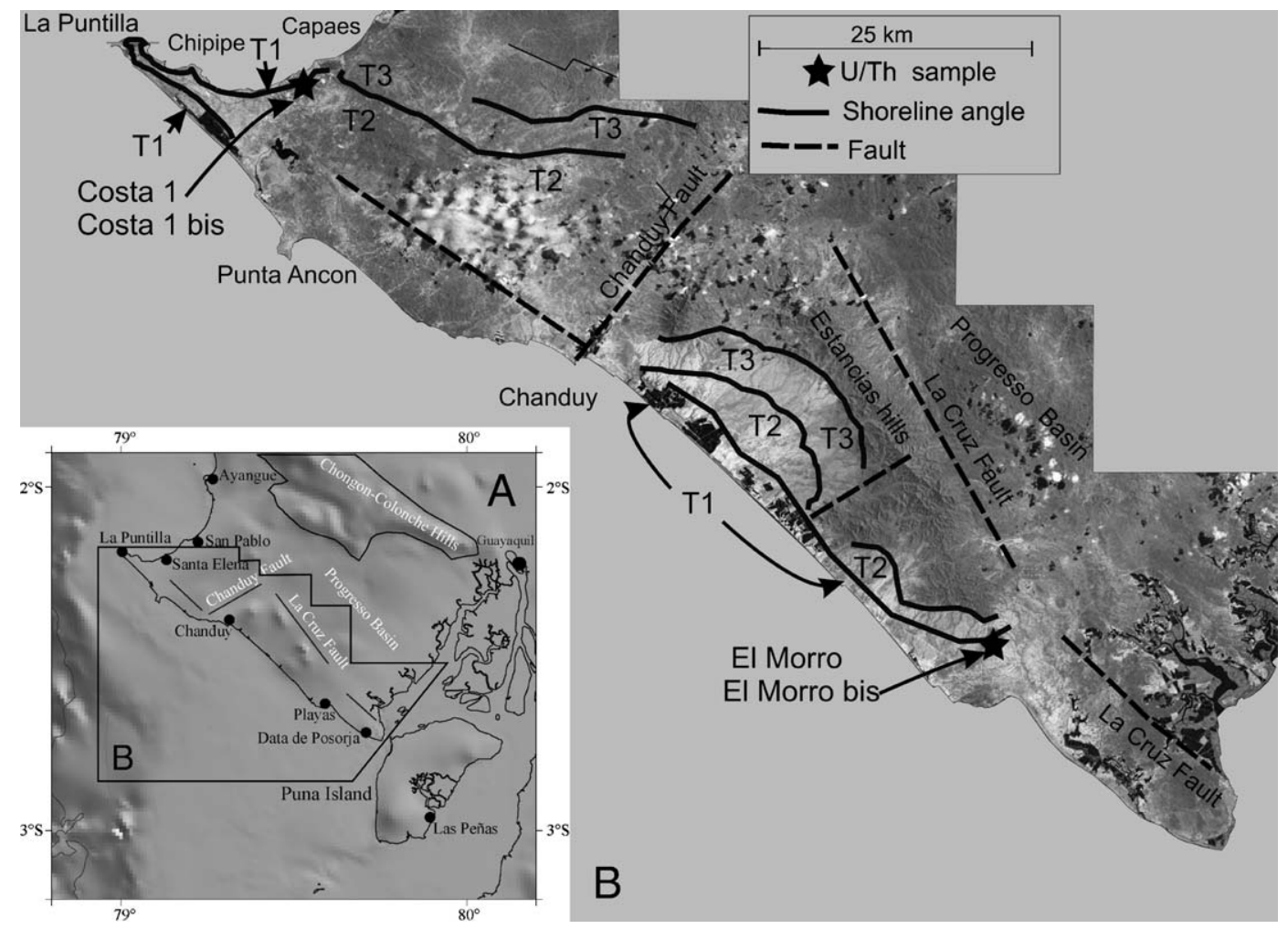

Fig. 5. Sequence III, Santa Elena Peninsula. (A) DEM of the studied area (B) Marine terraces on the Santa Elena Peninsula. Map is made on Landsat image available at https://zulu.ssc.nasa.gov/mrsid/.

(Fig. 7), range from 0.07 to $0.10 \mathrm{~mm} / \mathrm{yr}$ (Fig. 8). Assuming constant uplift through time, the calculated ages of $\mathrm{T} 2$ and $\mathrm{T} 3$ range between 400 and $500 \mathrm{ka}$ (T2), and 600 and $900 \mathrm{ka}$ (T3). This assumed relatively slow uplift, as observed in the Gulf of Guayaquil area, would be favourable to re-occupation of pre-existent platforms during successive highstands (Kelsey and Bockheim, 1994; Trenhaile, 2001, 2002). As Dumont et al. (2005), we tentatively propose that MIS $9(330 \mathrm{ka})$ and/or 11 (440 ka) transgressions are responsible for the formation of the wide and complex T2 terrace, whereas the T3 terrace may have to be attributed to early-middle Pleistocene highstands.

\subsection{Northern Peru}

The marine terraces of northern Peru between $3.5^{\circ} \mathrm{S}$ and $6.5^{\circ} \mathrm{S}$ cover a wide surface of up to $20000 \mathrm{~km}^{2}$ (Fig. 6). The largest marine terraces are called "tablazo" from a local descriptive name, and scientific attention has been paid to them since 1916 (Berry in Bosworth, 1922). Partial studies using the modern concept of marine terraces were carried out (DeVries, 1984, 1986, 1988; Macharé and Ortlieb, 1994) but this presentation constitutes the first general overview of the marine terraces in this area. All over the zone, the altitude repartition of the shoreline angle corresponds to a series of low ( $<100 \mathrm{~m}$ ), distinct ( 2 to 4$)$ platforms, overlooked by the wide and complex "tablazos" (Talara and Mancora) up to an altitude of $305 \mathrm{~m}$.

\subsubsection{Cancas (sequence IVa and IVb)}

4.2.1.1. Description. From $3.5^{\circ} \mathrm{S}$ to $4^{\circ} \mathrm{S}$, low marine terraces are found along the northern Peruvian coast. North of Cancas (Fig. 6) a sequence of three marine terraces T1, T2, T3, is observed near Acapulco (Sequence IV a, Figs. 6 and 7). The shoreline angles of T1, T2 and T3 were found at $15 \pm 5,30 \pm 5$ and $50 \pm$ $5 \mathrm{~m}$, respectively. The $\mathrm{T} 1$ terrace is not as developed as $\mathrm{T} 2$ and includes coastal lagoon deposits. Marine terrace T2 is well exposed and its shoreline angle is conspicuous in the landscape. In some places, this terrace reoccupies a former terrace (T3) which is much more dissected, and hard to observe. South of Cancas the sequence IVb (Figs. 6 and 7) includes two marine terraces T3 and T4 preserved over a 7-km-long coastal strip, and showing shoreline angles at the elevations of $52 \pm 5$ and $92 \pm 5 \mathrm{~m}$, respectively. Marine terraces T3 and $\mathrm{T} 4$ are both highly dissected and their erosion can 

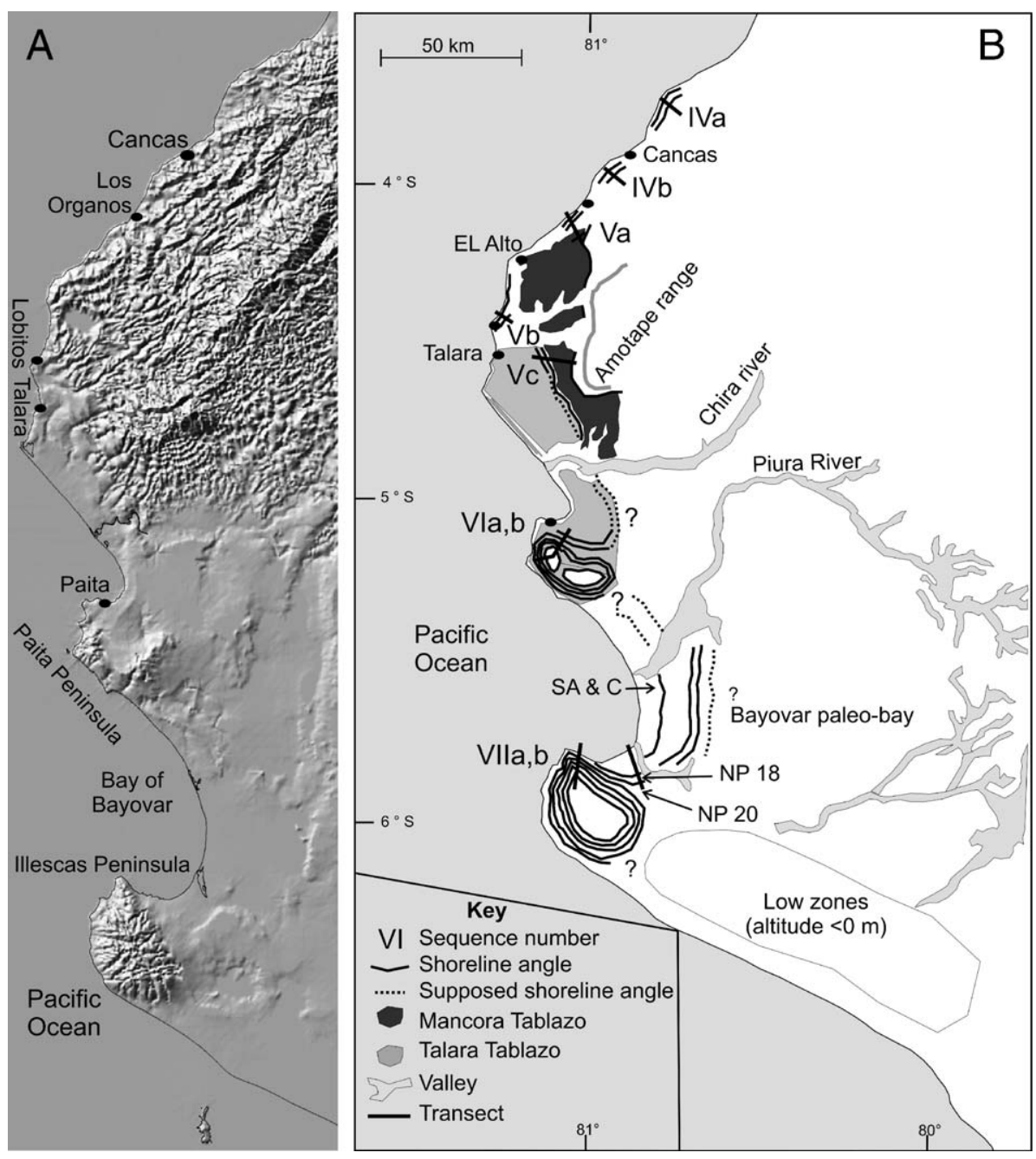

Fig. 6. Sequences IV, V, VI, VII in Northern Peru. (A) DEM of the studied area (B) Marine terraces distribution. NP: IRSL samples. SA \& C: ${ }^{14}$ C samples Sechura and Sechura C.

be compared with T3 in sequence IVa. These marine terraces present poorly consolidated sandy deposits overlying the Talara Formation (Eocene). The coastal morphology and the erosion of the terraces lead us to the interpretation that the $\mathrm{T} 1$ and $\mathrm{T} 2$ marine terrace were removed or never eroded in the second place.

\subsubsection{Tentative chronostratigraphic interpretation} and uplift rates. Along this coastal stretch, the most conspicuous terrace is the Tablazo Lobitos (DeVries, 1986, 1988; Macharé and Ortlieb, 1994). The altitude of its shoreline angle ranges between 18 and $30 \mathrm{~m}$. This marine terrace is extremely well preserved and has been morpho-stratigraphically attributed to MISS 5e (Macharé and Ortlieb, 1994). In consequence, we propose correlating $\mathrm{T} 1$ and $\mathrm{T} 2$ from sequence IVa to MIS 5. This interpretation leads to an estimation of local uplift of $0.2 \pm 0.05$ $\mathrm{mm}$, if it is considered that the $\mathrm{T} 2$ shoreline angle (as the Lobitos Tablazo) was carved during substage 5e (120 ka). Assuming constant uplift through time, the ages of T3 and T4 would range between 188 and 380 (T3) and 350 and $650 \mathrm{ka}$ (T4). Due to slow uplift, T3 and T4 are probably complex terraces (platform re-occupation) carved, respectively, during MIS 7 and 9 (T3) and 11 to 13 (T4).

\subsubsection{Mancora (sequences $\mathrm{Va}$ and $\mathrm{Vb}$ )}

The Mancora area is characterized by the wide and complex Mancora Tablazo (Bosworth, 1922), a low dipping platform between 160 and $300 \mathrm{~m}$ in elevation. DeVries (1986) proposed that the Mancora Tablazo (TM) is composed of at least two parts: a high and low Mancora Tablazo. Our observations support DeVries's 


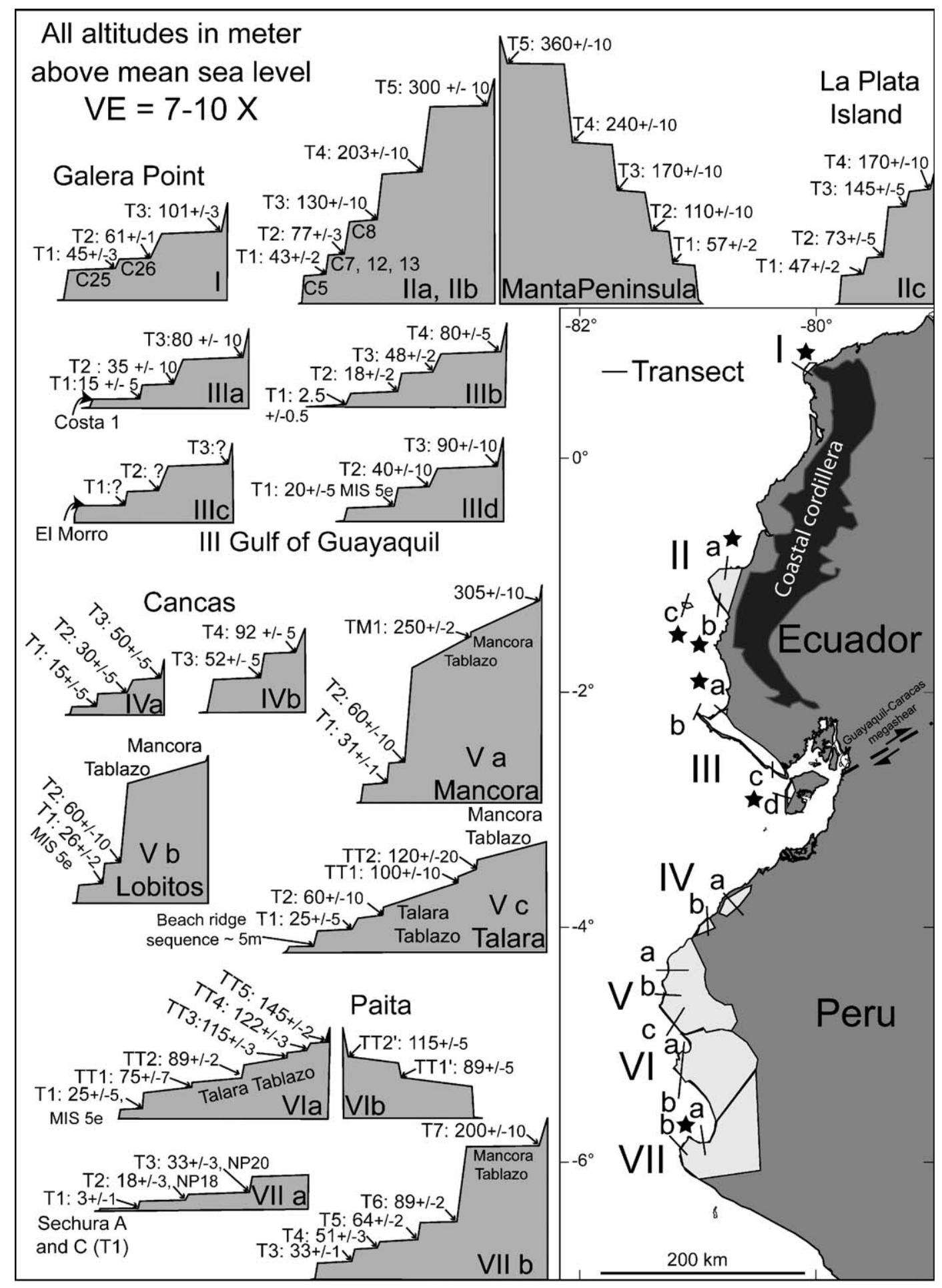

Fig. 7. Altitudes of the marine terraces along the Talara Arc. All transects are represented. Black stars show where some terraces of the sequences have been dated. The sample names (NP, Sechura, El Morro for example) are written on the transects. MIS or MISS assigned to a specific terrace by previous author, are reported. See text for details. 
redefinition of Bosworth nomenclature (1922). In other words, the Mancora Tablazo corresponds to a marine terrace sequence. The Mancora Tablazo overlooks two "low" terraces that are well developed in the areas of Los Organos and Lobitos.

\subsubsection{Description}

4.2.2.1.1. Los Organos (sequence Va). South of Los Organos village, the Va sequence of T1 and T2 terraces crops out along a 10-km-long coastal segment (Fig. 6), with shoreline angles at the respective altitudes of $31 \pm 1$ and $60 \pm 10 \mathrm{~m}$ (Fig. 7). As in the Cancas area, marine terrace T1 is well developed whereas T2 only constitutes discontinuous patches on the hilltop. On T1 a $1.5-\mathrm{m}-$ thick layer of beach sand discordantly overlies the Taime formation. It is covered by recent colluvium only $15 \mathrm{~m}$ away from the shoreline angle but is not suitable for sampling. No marine deposits were found associated with the T2 terrace. The marine terrace sequence constituting the Mancora Tablazo has a distal edge at about $160 \mathrm{~m}$ and an upper shoreline angle (TM1) at 305 $\pm 10 \mathrm{~m}$. A $20 \mathrm{~m}$ high cliff at an altitude of $250 \pm 10 \mathrm{~m}$ is interpreted as an intermediate shoreline angle; other intermediate shoreline angles are also present. In some places, the Mancora Tablazo includes a thin cover of shallow sand overlying discordantly the Taime Formation.

4.2.2.1.2. Lobitos (sequence $\mathrm{Vb}$ ). The Lobitos sequence $\mathrm{Vb}$ is very similar to Los Organos sequence Va, including two marine terraces $\mathrm{T} 1$ and $\mathrm{T} 2$ and the Mancora Tablazo. The terrace $\mathrm{T} 1$ has been found at an elevation of $26 \pm 2 \mathrm{~m}$, and $\mathrm{T} 2$ at $60 \pm 10 \mathrm{~m}$ (Fig. 7).

\subsubsection{Tentative chronostratigraphic interpretation} and uplift rates. The size and continuity of the former Lobitos Tablazo (T1 terrace of this study) supports an assignment to MISS 5e, as proposed by Machare and Ortlieb (1994). This interpretation suggests mean uplift rates of $\sim 0.20 \mathrm{~mm} / \mathrm{yr}$ for the late Quaternary. As to the north, the age of terrace T2 overlooking the former Tablazo Lobitos (T1) can be inferred from uplift rates if it is assumed constant through time. Taking into account error ranges (altitude of $\mathrm{T} 2$ shoreline and uplift rates on $\mathrm{T} 1$ ), it is inferred that the T2 shoreline angle was carved between 200 and $350 \mathrm{ka}$. Thus, T2 marine terrace was probably a complex terrace carved during MIS 7 and/or 9. On the basis of assumed local mean uplift rate ranging between 0.1 and $0.3 \mathrm{~mm} / \mathrm{yr}$ (mean of $0.2 \pm 0.1 \mathrm{~mm} / \mathrm{yr}$ ) for middle and late Pleistocene times, the Mancora Tablazo may have been formed between 1.6 and $3 \mathrm{Ma}$ $(0.1 \mathrm{~mm} / \mathrm{yr})$ or between 0.5 and $1 \mathrm{Ma}(0.3 \mathrm{~mm} / \mathrm{yr})$.

\subsubsection{Talara Tablazo (sequence Vc)}

The harbour of Talara gives its name to the spectacular tablazo that overlooks the port and the city. The elevation of the Talara Tablazo (TT) ranges from $70 \pm 10 \mathrm{~m}$ (edge of cliff at Talara) up to at least 120 $\pm 20 \mathrm{~m}$, the elevation of a topographic angle on the lower slopes of the Amotape hills (Figs. 6 and 7). The Talara Tablazo is present above a sequence of two low marine terraces (T1 and T2) and a beach ridge sequence (sequence Vc on Fig. 6) in the Colan area. The beach ridge sequence and the two low marine terraces $\mathrm{T} 1$ and $\mathrm{T} 2$ are found at respective altitudes of $\sim 5 \mathrm{~m}, 25 \pm 5$ (T1) and $60 \pm 10 \mathrm{~m}$ (T2). The Mancora Tablazo (MT) overlooks the Talara Tablazo (TT) on the western flank of the Amotape hills, with an altitude of $\sim 300 \mathrm{~m}$. The Talara Tablazo includes several individual and overlapping terraces identified by small scarps interpreted as intermediate shoreline angles, but in this zone, they are not clear enough to be taken into account in a morphologic succession.

\subsubsection{Paita Peninsula (sequence $\mathrm{Va}$ and $\mathrm{Vb}$ )}

4.2.4.1. Description. The Paita Peninsula (Fig. 6) includes Palaeozoic rocks (shale and granite) discordantly covered by Cretaceous volcanic rocks (Palacios et al., 1989). Towards the sea the peninsula presents a 50-60 m sea cliff, with evidence of low marine terraces $\mathrm{T} 1$ and $\mathrm{T} 2$ at $25 \pm 5$ and $60 \pm 10 \mathrm{~m}$ north of Paita Bay (Macharé and Ortlieb, 1994). We describe sequences of marine terraces, respectively, from the NNE (VIa) and $\mathrm{SSW}(\mathrm{VIb})$ slopes of the peninsula, the NNE terraces being more sharply cut than those to the SSW (Fig. 7). The basement favoured conservation of distinct shorelines, which correspond to intermediate shorelines of the Talara Tablazo. Consequently we numbered these terraces TT1, TT2 etc...

The sequence VIa includes five marine terraces with shoreline angles at the following altitudes: TT1: $75 \pm 7$; TT2: $89 \pm 2$; TT3: $115 \pm 3$; TT4: $122 \pm 2$ and TT5: $145 \pm 2$ $\mathrm{m}$ (Fig. 7). The TT2 terrace presents a continuous belt around the Paita hills, whereas the TT1 shoreline is hardly noticeable in the landscape. The TT3 and TT4 marine terraces are fairly narrow $(<100 \mathrm{~m}$ in width) and the altitude of their respective shoreline angles is quite close $(\sim 7-8 \mathrm{~m})$. The TT5 marine terrace is wider than $200 \mathrm{~m}$, with a clear 30-m-high paleo-sea cliff on the upper part of the Paita Peninsula. It probably corresponds to the highest shoreline angle of the Tablazo Talara. Therefore the Tablazo would include at least 5 distinct terraces. The $\mathrm{Vb}$ sequence on the SSW flanks of the Paita Peninsula includes two marine terraces TT1 
and TT2 with their shoreline angles at the respective altitudes of $89 \pm 4$ and $115 \pm 5 \mathrm{~m}$. These are morphologically correlated with the equivalent terraces of the other flank of the Paita hills (Fig. 7). As the two sequences are numbered independently, the TT2 terrace of the NNE slopes of the hills constituting the core of the peninsula, is equivalent to the TT1 terrace of the SSW slopes. The terraces from the NNE slopes are morphologically better defined, but no deposits were found.

\subsubsection{Tentative chronostratigraphic interpretation} and uplift rates. A low terrace (T1) located north of the Paita Peninsula at an elevation of about $25 \pm 5 \mathrm{~m}$, has been correlated with the MISS 5e by Macharé and Ortlieb (1994). This interpretation suggests a local late Quaternary uplift rate of $0.16 \pm 0.05 \mathrm{~mm} / \mathrm{yr}$. In Northern Peru, uplift since the last interglacial maximum (MISS $5 \mathrm{e})$ could be considered to have been relatively constant $(\sim 0.20 \pm 0.05 \mathrm{~mm} / \mathrm{yr})$ over long distances $(>100 \mathrm{~km})$. Based on an extrapolation of the regional (steady) uplift rates $(\sim 0.20 \pm 0.05 \mathrm{~mm} / \mathrm{yr})$, we surmise that the formation of the terrace sequence, including 5 intermediate shoreline angles in the Tablazo Talara, encompassed the period between about $700 \mathrm{ka}$ to $1 \mathrm{Ma}$ ago and MIS 11 (400 ka) or MIS 9 (330 ka).

\subsubsection{The Bay of Bayovar and the Illescas Peninsula (Sequences VIIa and VIIb)}

4.2.5.1. Description. South of the Paita Peninsula, the Bay of Bayovar is limited to the south by the Illescas Peninsula, which constitutes the southernmost peninsula of the Talara Arc (Fig. 6). Low marine terraces T1 ( $3 \pm 1$ $\mathrm{m}), \mathrm{T} 2(18 \pm 3 \mathrm{~m})$ and $\mathrm{T} 3(33 \pm 5 \mathrm{~m})$ are observed in this bay. Palaeozoic shale and quartzite surround the gneissic core of the Illescas Peninsula. This material favoured the formation and preservation of 4 marine terraces, T4 (51 $\pm 3 \mathrm{~m}), \mathrm{T} 5(64 \pm 2 \mathrm{~m}), \mathrm{T} 6(89 \pm 2 \mathrm{~m})$ and T7 $(200 \pm 10 \mathrm{~m})$ (Figs. 6 and 7). As for the Paita Peninsula the terraces on the NNE slopes of the peninsula are better preserved than those of the SSW slopes. The upper T7 terrace is up to $4 \mathrm{~km}$ wide and surrounds the summit of the Illescas Peninsula, overlying the Plio-Quaternary Tric-Trac Formation.

The sequence VIIa (Fig. 7) includes the T1 to T3 marine terraces observed in the southern part of the Bay of Bayovar and the sequence VIIb the T4 to T7 terraces observed on the northern slopes of the peninsula. The T3 terrace shows the continuity of the sequence from the Bay of Bayovar to the Illescas Peninsula. The T1 terrace $(3 \pm 1 \mathrm{~m})$ is well developed in the Bay of Bayovar, constituting the $10 \mathrm{~km}$ wide Salinas level described by
Macharé and Ortlieb (1994). The paleo sea cliff of T1 is up to $5 \mathrm{~m}$ high; with a shoreline angle at an elevation of $3 \pm 1 \mathrm{~m}$. Currently, a long beach ridge that is only washed during El Nino periods protects this terrace from marine invasion. Fossils shells of Chione sp, Turitella sp, Anomia peruana and Megabalannus sp found in life positions in the sand, less than $50 \mathrm{~m}$ from the shoreline angle, provided ${ }^{14} \mathrm{C}$ dating (Samples Sechura A and C, Table 4) but no useful results (see further). The T2 (18 $\pm 3 \mathrm{~m}$ ) terrace includes shallow sandy deposits that have been sampled for IRSL dating (NP 18) and accumulation of Argopecten sp. and Ostrea megodon shells. The T3 $(33 \pm 5 \mathrm{~m})$ terrace is clearly observed along the main road to Sechura, and beach sand from this terrace provided material for IRSL dating (NP20). On the northern flank of the Illescas Peninsula, the T3 terraces stands at an elevation of $33 \pm 1 \mathrm{~m}$, completing the continuity of the marine terrace sequence from the Bay of Bayovar to the peninsula (sequence VIIb, Fig. 7). The following T4 to T7 terraces appear as platforms without any sediment or fossil material suitable for sampling.

\subsubsection{Tentative chronostratigraphic measurements} and uplift rates. Samples for dating come from the T1 $\left({ }^{14} \mathrm{C}\right), \mathrm{T} 2$ and T3 (IRSL) terraces. The two ${ }^{14} \mathrm{C}$ samples (Sechura A and C) from T1 $(3 \pm 1 \mathrm{~m})$ yielded results at the limit of the method ( $38 \mathrm{ka}$, Table 4$)$. They must be considered as minimum ages, because the shells were found in life position. Sample NP18 from the wide T2 terrace yields a corrected IRSL age of $111 \pm 8 \mathrm{ka}$ (Table 1). Because of the continuity of $\mathrm{T} 1$ over a long distance (see before) and the IRSL dating, we propose assigning $\mathrm{T} 2$ to the MISS $5 \mathrm{e}$.

Sample NP20 from T3 $(33 \pm 5 \mathrm{~m})$ had high radioactivity (strong annual dose), probably due to recent contamination or post diagenetic uptake. Considering an annual dose equal to that of NP18 ( 2.8, NP20-3, Table $1)$, NP20 gives a minimum IRSL age of $172 \pm 23 \mathrm{ka}$ : this supports a correlation with the MIS $7(\sim 220 \mathrm{ka})$. The fairly weak morphological expression of $\mathrm{T} 3$ is also an argument for this interpretation. Assignment of T2 to

Table 4

${ }^{14} \mathrm{C}$ results (Beta Analytics, Miami USA) on seashells from marine terraces deposits of the Talara Arc

\begin{tabular}{llll}
\hline Sample data & $\begin{array}{l}\text { Measured } \\
\text { radiocarbon age }\end{array}$ & $\begin{array}{l}{ }^{13} \mathrm{C} /{ }^{12} \mathrm{C} \\
\text { ratio }\end{array}$ & $\begin{array}{l}\text { Conventional } \\
\text { radiocarbon age }\left({ }^{\mathrm{a}}\right)\end{array}$ \\
\hline Sechura A & $36940 \pm 990 \mathrm{BP}$ & $0.0^{\mathrm{a}} \mathrm{o} / \mathrm{oo}$ & $37350 \pm 1040^{\mathrm{a}} \mathrm{BP}$ \\
Sechura C & $37210 \pm 740 \mathrm{BP}$ & $0.0^{\mathrm{a}} \mathrm{o} / \mathrm{oo}$ & $37620 \pm 780^{\mathrm{a}} \mathrm{BP}$ \\
\hline
\end{tabular}

Analysis: radiometric-standard delivery.

Material/pretreatment: (shell): acid etch.

a 2 sigma calibration: (result is outside of calibration range). 
MISS 5e and T3 to MIS 7 suggests a mean uplift rate ranging from 0.12 to $0.15 \mathrm{~mm} / \mathrm{yr}$. Extrapolation of a 0.13 $\pm 0.03 \mathrm{~mm} / \mathrm{yr}$ late Quaternary mean uplift rate provides an age range from 300 to $540 \mathrm{ka}$ for T4, 390 to $660 \mathrm{ka}$ for $\mathrm{T} 5$ and 550 to $910 \mathrm{ka}$ for T6. In conclusion, we suggest that T4 and T5 were created during Middle Pleistocene high seastands: MIS 9 and/or 11 for T4, MIS 11 and/or 13 for T5. The T6 terrace is tentatively assigned to an Early Middle Pleistocene high seastand, and the upper Tablazo (T7) to a pre-1 Ma sea stand. In this case the T7 terrace is somehow equivalent to the Mancora Tablazo to the north but is found at a lower altitude because of slower uplift rates. An assignment of the T2 terrace to MISS 5e implies that the T1 terrace may be younger than MISS 5e. Considering the result of ${ }^{14} \mathrm{C}$ dating, we propose an assignment of $\mathrm{T} 1$ to a sea level highstand between 40 and $130 \mathrm{ka}$ that fits with MISS 5a (85 ka) or $5 \mathrm{c}(105 \mathrm{ka})$.

\section{Discussion}

Net uplift rates calculated for MIS 5, 7, 9, 11 do not give evidence of significant change of uplift rates through time: variations through time are not representative of any tendency with respect to the error range. Thus, uplift rate variations along the coast of the Talara Arc can be analysed relative to MISS 5e, which is the most recent interglacial and the best constrained with respect to chronostratigraphical measurements (Fig. 8). Uplift rates determined for the Last Interglacial Maximum (LIM, MIS 5e) range between 0.10 (Santa Elena Peninsula, Sequence IIIa, c, Bayovar paleo-bay, sequence VIIa Fig. 8) and $0.42 \mathrm{~mm} / \mathrm{yr}$ (Manta peninsula, sequence IIb) (Fig. 8). Uplift rate variations suggest different scales of wavelength deformation, representing basically different scales of geodynamical structures, from less than 50 to $800-1000 \mathrm{~km}$ and more. The short wavelength of deformation $<50 \mathrm{~km}$ is generally related to local faults. For example, the Montecristi Fault on the Manta Peninsula (Figs. 8 and 9) has a long history, first as related to strike slip and transtension motion before the Pliocene (DGGM, 1970), and probably as a normal fault during the Quaternary (this study). The surrounding geology shows that the full section is affected down to the Mesozoic basement. The difference in uplift rates on both sides of this fault is about $0.1-0.15 \mathrm{~mm} / \mathrm{yr}$, if uplift is assumed to have been constant since MIS 9 (Figs. 8 and 9). The differences in steady uplift rate observed through time on both sides of the faults relate to larger scale processes than just local adjustment (i.e. some steady stretch stress acting at the scale of the Talara Arc).
In any case, the most striking characteristic of the Late Pleistocene Talara Arc uplift is its homogeneity over a long distance $(1000 \mathrm{~km})$. This long wavelength of deformation is suggested by the changes observed north and south of the Talara Arc. To the south of the Arc, the transition towards the stable or subsiding coast of Central Peru is relatively smooth: width of the coastal margin does not change significantly, but the orientation of the coast abruptly changes to nearly north-south. To the north, coastal uplift stops sharply on the NW-SE trending Las Peñas Fault (North of the Esmeraldas Fault, Fig. 9), which limits the subsiding Borbon basin. This long wavelength of deformation is also suggested by the relative homogeneity of the Late Quaternary uplift along the arc itself (Fig. 8) producing a "dome" shape. Toward the northern and southern ends of the arc, the Late Pleistocene uplift rates slow down progressively to $0.12 \mathrm{~mm} / \mathrm{yr}$ to the south and $0.34 \mathrm{~mm} / \mathrm{yr}$ to the north. This asymmetrical pattern is attributed to the effect of subduction of the buoyant Carnegie ridge that transferred to the Ecuadorian coast an excess uplift estimated as $0.2 \pm 0.1 \mathrm{~mm} / \mathrm{yr}$.

Recently, Pedoja et al., (2001; accepted) compared the Late Quaternary coastal uplift in front of the Carnegie Ridge (Manta Peninsula and La Plata Island) to coastal uplift in front of other South American Ridges: 1) the Cocos Ridge in Costa Rica, and 2) the Nazca Ridge in Peru (Fig. 1). The main conclusion of this work is that the coastal Quaternary uplift in front of Carnegie Ridge is reduced when compared to other coastal regions in a similar structural context. In front of the Cocos Ridge, the highest uplift rates range from 6.5 to $2.1 \mathrm{~mm} / \mathrm{yr}$ (Gardner et al., 1992), and a Quaternary uplift rate of $1 \mathrm{~mm} / \mathrm{yr}$ has been proposed from subaerially exposed Plio-Pleistocene turbiditic sediments (Corrigan et al., 1990). In front of the Nazca ridge (Southern Peru), the uplift documented by marine terraces is estimated by Hsu (1992) to be 0.47 and $0.7 \mathrm{~mm} / \mathrm{yr}$ by Machare and Ortlieb (1992). The relatively slow vertical reaction of the Ecuadorian coast in front of the subducting ridge is interpreted to be related to the northeastward motion of the North Andean Block.

If Pleistocene uplift for the Ecuadorian coast can be related to the subduction of Carnegie Ridge, it is more difficult to determine the origin of the North Peruvian uplift. The main result of the study (i.e. slow to moderate uplift over more than $1000 \mathrm{~km}$ of coast) leads us to consider the Talara Arc as a homogenous structure. In fact, the plan view of the Talara Arc fits precisely the limits of the curved coast segment affected by uplift. We discard an interpretation joining together the effects of 


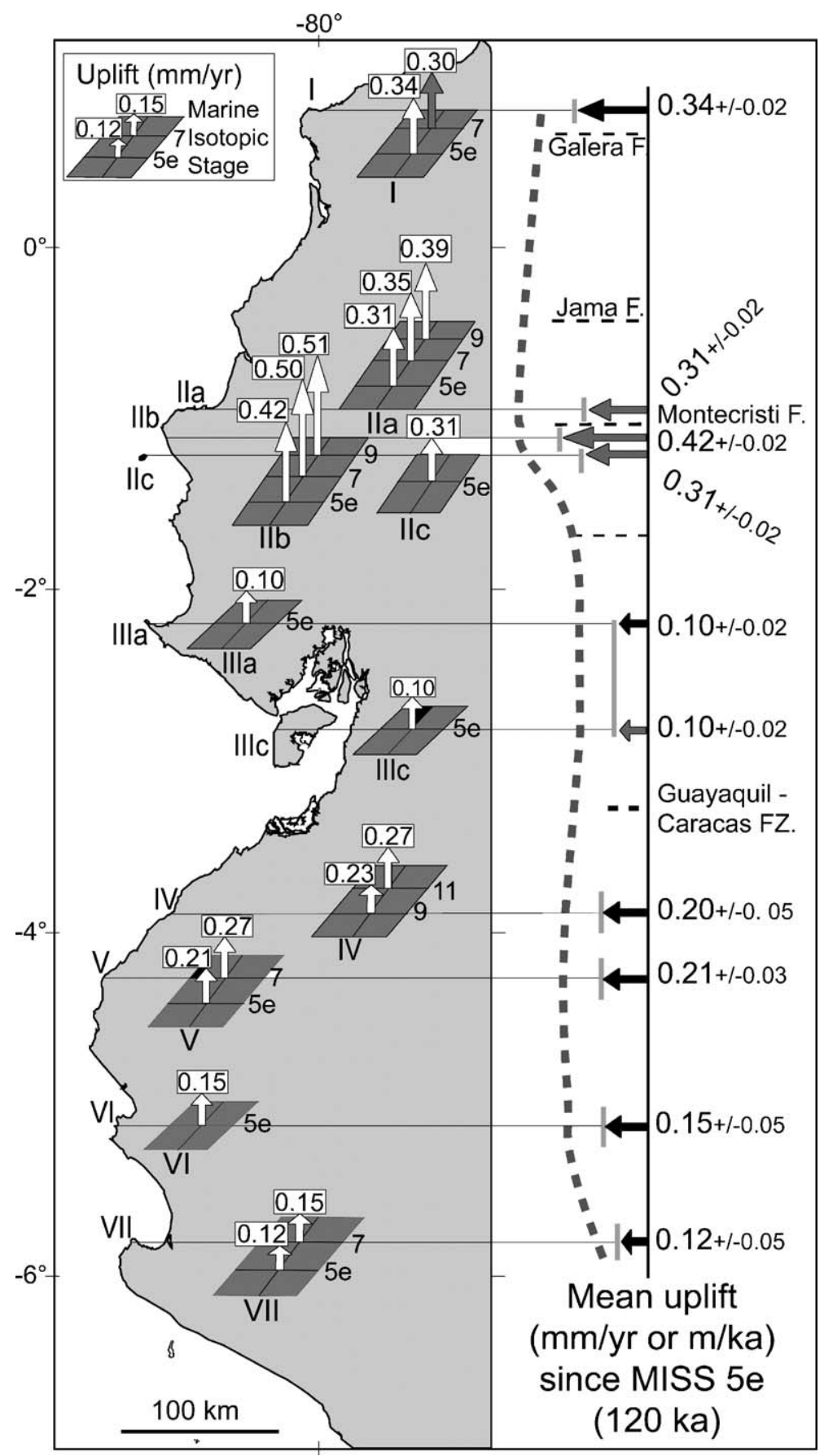

Fig. 8. Graphic representation of the uplift rates deduced from the marine terraces along the Talara Arc. The wavelength of deformation is represented to the right.

several local uplifts because of the apparent homogeneity of the large-scale uplift along the arc. The Talara Arc features a cape, a "prow", relative to the subducting Pacific Plate, and it can be hypothesized that the heading edge part of the prow tends to be lifted relative to the sides. The present shape of the Talara Arc was acquired after post-Oligocene and prior to the middle Miocene times, thus it far-predates the oldest marine terraces observed along the arc. Some recent results supported by a concave-subduction analogical model (Bouteillier, 2004) show that concavity tends to produce uplift of the overriding plate. This light uplift may be maintained 


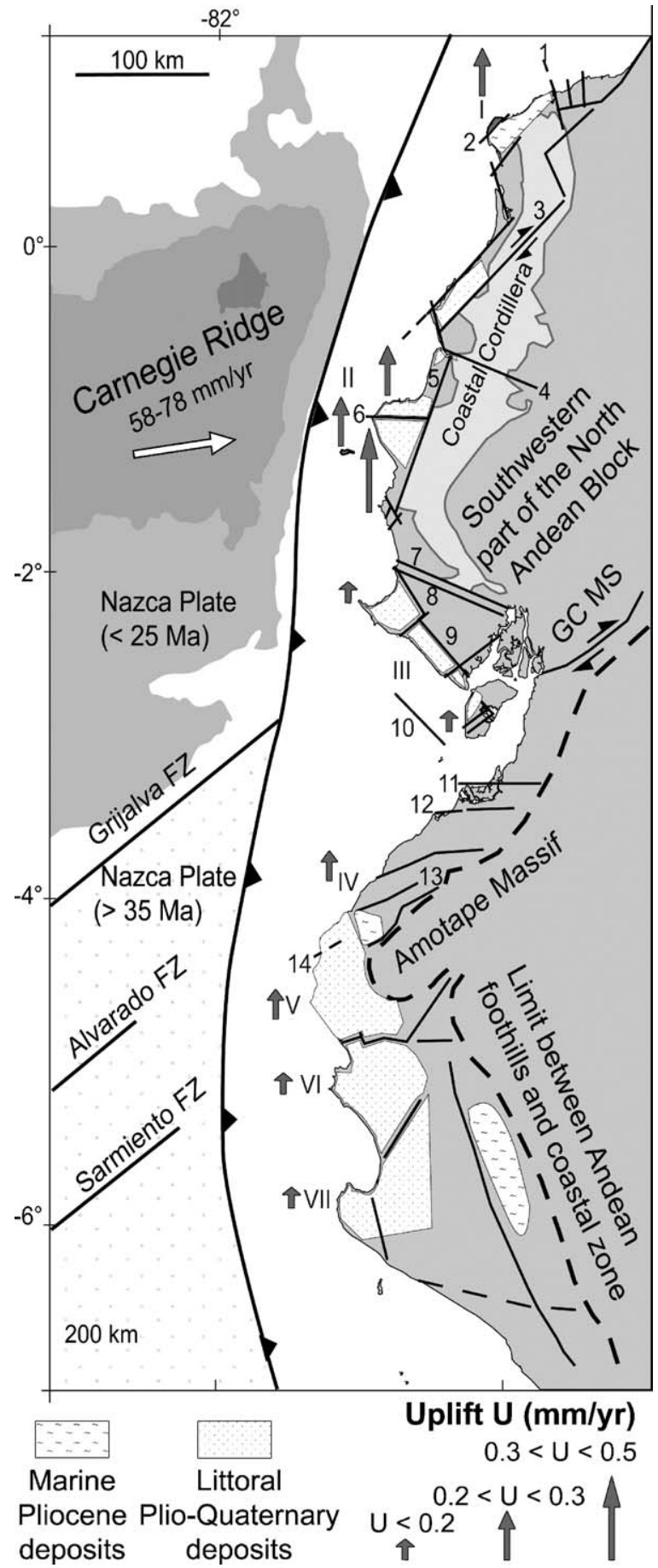

Fig. 9. Structural frame and coastal uplift along the Talara Arc. Main faults are reported from the geological maps (DGGM, 1969, 1970, 1974, 1975, 1980). GC MS Guayaquil-Caracs megashear. 1 Esmeraldas, 2 Galera, 3 Jama, 4 Bahia, 5 Portoviejo, 6 Montecristi, 7 colonche, 8 Carrizal, 9 La Cruz, 10 Posorja, 11 Tumbes, 12 Portovelo, 13 Cancas, 14 Restin. through time by the aerial erosion of the continent margin. The observation of numerous Cretaceous (Ecuador) or older basement outcrops (north Peru) observed in the capes and peninsulas along the coast supports this hypothesis. In other words, the whole Talara Arc has a tendency to uplift and subduction of the Carnegie Ridge introduces a relatively weak excess uplift to the main zone.

\section{Conclusions}

The coast of the Talara Arc is uplifted along a concave subduction zone. Late Quaternary uplift rates range from $0.10 \mathrm{~mm} / \mathrm{yr}$ up to a maximum of $0.42 \mathrm{~mm} / \mathrm{yr}$ in the Manta Peninsula in front of the axis of the Carnegie Ridge. Compared to other example of Quaternary coastal uplift, the main uplift registered along the Talara Arc, relative to stable or subsiding straight segments to the north and south, is interpreted as the geometrical effect of a concave subduction zone. Coastal uplift during the Quaternary is interpreted as an effect of the shape of the arc itself, the uplift being maintained through time by erosion on the coastal margin of Ecuador and subduction of the Carnegie Ridge. Such studies of Pleistocene and coastal evolution and neotectonics will help out to elucidate other complex subduction zones such as those characteristics of western South America.

\section{Acknowledgments}

This work was partially funded by the IRD (French Institute for Investigation and Development) and is based on the first author's doctoral thesis, undertaken in the Geosciences Azur Laboratory (Paris 6) and in the framework of a cooperative contract while KPM acted as a scientist in Petroproduccion Guayaquil (Ecuador). The finalization of this work was allowed and supported by 1) CAS (The Chinese Academy of Sciences) Hundred Talents Program and 2) the Key Laboratory of Marginal Sea Geology, South China Sea Institute of Oceanology. Alexandre Chemanda is thanked for the interesting discussion about concave subduction. This work is part of the activities of the IGCP project 495, Quaternary Land Ocean Interaction: Driving Mechanisms and Coastal Responses.

\section{References}

Aitken, M.J., 1985. Thermoluminescence Dating. Academic Press, London. 359 pp. 
Aitken, M.J., 1998. An Introduction to Optical Dating. Oxford University Press, Oxford. 267 pp.

Auclair, M., Lamothe, M., Bouab, N., Huot, S., Jennane, A., Pedoja, K., 2002. The measurement and correction of anomalous fading of feldspar IRSL using SAR. 10th International Conference on Luminescence and Electron Spin Resonance Dating. Reno, USA, p. 74 .

Bosworth, T.O., 1922. Geology of the Tertiary and Quaternary periods in the northwest part of Peru. MacMillan an Company, London.

Bouteillier, D., 2004. La modélisation expérimentale tridimensionnelle thermomécanique de la subduction continentale et l'exhumation des roches de ultra haute pression/basse températureNice SofiaAntipolis, Nice.

Bristow, C.R., Hoffstetter, R., 1977. Léxique Stratigrapgique, Amérique Latine. Ed CNRS, Paris, Fas. 5 à 2, Ecuador: 410.

Bull, W.B., 1985. Correlation of flights of global marine terraces. In: Morisawa, M., Hack, J. (Eds.), 15th Annual Geomorphology Symposium. State University of New York, Binghampton, pp. $129-152$.

Cantalamessa, G., Di Celma, C., 2004. Origin and chronology of Pleistocene marine terraces of Isla de la Plata and of flat, gently dipping surfaces of the southern coast of Cabo San Lorenzo (Manabi, Ecuador). J. South Am. Earth Sci. 16, 633-648.

CERESIS, 1985. Mapa neotectonico preliminar de America del Sur.

Corrigan, J., Mann, P., Ingle, J.C., 1990. Forearc response to subduction of the Cocos Ridge, Panama-Costa Rica. Geol. Soc. Amer. Bull. 102, 628-652.

Daly, M.C., 1989. Correlations between Nazca/Farallon plate kinematics and forearc basin evolution in Ecuador. Tectonics 8 (4), 769-790.

De Mets, C., Gordon, R.G., Argus, D.F., Stein, S., 1989. Current plate motions. Geophys. J. 101, 425-478.

Deniaud, Y., 2000. Enregistrement sédimentaire et structural de l'évolution géodynamique des Andes équatoriennes au cours du Néogène: étude des bassins d'avant-arc et bilans de masse, Université Joseph Fourier-Grenoble I. Grenoble. 242 pp.

Deniaud, Y., Baby, P., Basile, C., Ordoñez, M., Montenegro, G., Mascle, G., 1999. Opening and tectonic and sedimentary evolution of the Gulf of Guayaquil: Neogene and Quaternary fore-arc basin of the south Ecuadorian Andes. Comptes Rendus de l'Académie des Sciences - Series IIA. Earth Planet. Sci. 328 (3), 181-187.

DeVries, T.J., 1984. Neotectonica del area de Cabo Blanco Noroeste del Peru. Boletin de la Sociedad Geologica del Peru 73, 1-12.

DeVries, T.J., 1986. The Geology and Paleontology of Tablazos in Northwest Peru. Graduate Thesis, Ohio State University. 671 pp.

DeVries, T.J., 1988. The geology of late Cenozoic marine terraces (tablazos) in northwestern Peru. Journal of South American Earth Sciences 1 (2), 121-136.

DGGM, 1969. Mapa Geologico de la Republica del Ecuador. Instituto Geografico Militar, Quito.

DGGM, 1970. Mapa Geologico Detallado del Ecuador, hoja Montecristi. Ministerio de Recursos Naturales y Turismo, Quito.

DGGM, 1974. Mapa Geologico del Ecuador, Hoja Chanduy. Direccion General de Geologia y Minas, Quito.

DGGM, 1975. Mapa Geologico del Ecuador, Hoja Estero Salado. Direccion General de Geologia y Minas, Quito.

DGGM, 1980. Mapa geologico del Ecuador, Hojas 24 y 7, Esmeraldas and Punta Galera, scale $1 / 100,000^{\circ}$. Direccion General de Geologia y Minas, Quito.

Dumont, J.F., Santana, E., Wilema, W., Pedoja, K., Ordoñez, M., Cruz, M., Jimenez, N., Zambrano, I., 2005. Morphological and microtectonic analysis of Quaternary deformation from Puna and Santa Clara Islands, Gulf of Guayaquil, Ecuador (South America). Tectonophysics 399 (1-4), 331-350.

Ego, F., Sebrier, M., Lavenu, A., Yepes, H., Eguez, A., 1996. Quaternary state of stress in the Northern Andes and the restraining bend model for the Ecuadorian Andes. Tectonophysics 259, $101-116$.

Feininger, T., 1980. La geología histórica del Cretácico y Paleógeno de la Costa Ecuatoriana, Politécnica. Monografía de, p. 745.

Ganser, A., 1973. Facts and theories on the Andes. J. Geol. Soc. (Lond.) 129, 93-131.

Gardner, T.W., Verdonck, D., Pinter, N., Slingerland, R., Furlong, K.P., Bullard, T.F., Wells, S.G., 1992. Quaternary uplift astride the aseismic Cocos Ridge, Pacific coast, Costa Rica. Geol. Soc. Am. Bull. 104, 219-232.

Guillier, B., Chatelain, J.L., Jaillard, E., Yepes, H., Poupinet, G., Fels, J.F., 2001. Seismological evidence on the geometry of the orogenic system in central northern Ecuador (South America). Geophys. Res. Lett. 28 (19), 3749-3752.

Gutscher, M.A., Malavieille, J.S.L., Collot, J.-Y., 1999. Tectonic segmentation of the North Andean margin: impact of the Carnegie ridge collision. Earth Planet. Sci. Lett. 168, 255-270.

Herbert-Veeh, H., 1966. Th230/U238 and U234/U238 ages of Pleistocene high sea level stand. J. Geophys. Res. 71 (14), 3379-3386.

Hoffstetter, R., 1948. Notas sobre el cuaternario de la peninsula de Santa Elena (Ecuador). Boletin de Informaciones Cientificas Nacionales II(11 et 12), pp. 19-44.

Hsu, J.T.-J., 1992. Quaternary uplift of the Peruvian coast related to the subduction of the Nazca Ridge: 13.5 to 15.6 degrees south latitude. Quat. Int. 15-16, 87-97.

Huntley, D.J., Lamothe, M., 2001. Ubiquity of anomalous fading, its measurement, and correction for it in optical dating of K-feldspars. Canadian J. Earth Sci. 38 (18), 1093-1106.

Jaillard, E., Ordoñnez, M., Benitz, S., Jimenez, G., Montengro, N., Zambrano, G., 1995. Basin development in an accretionary, oceanic-floored fore-arc setting: southern coastal Ecuador during Late Cretaceous-Late Eocene times. In: S.S.R.a.W.H.J., Tankard, A.J. (Eds.), Petroleum Basins of South America. American Association of Petroleum Geologists, pp. 615-631.

Kellogg, J.N., Vega, V., 1995. Tectonic development of Panama, Costa Rica and the Colombian Andes: Constraints from Global Positioning System geodetic studies and gravity. Geol. Soc. Am. Special Paper 295, 75-90.

Kelsey, H.M., Bockheim, J.G., 1994. Coastal landscape evolution as a function of eustasy and surface uplift rate, Southern Cascadia margin, USA. Geol. Soc. Am. Bull. 106, 840-854.

Lamothe, M., Auclair, M., 1999. A solution to anomalous fading and age shortfalls in optical dating of feldspar minerals. Earth and Planetary Science Letters 171, 319-323.

Lonsdale, P., 1978. Ecuadorian subduction system. Am. Assoc. Pet. Geol. Bull. 62 (12), 2454-2477.

Macharé, J., Ortlieb, L., 1992. Plio-Quaternary vertical motions and the subduction of the Nazca Ridge, central coast of Peru. Tectonophysics 205, 97-108.

Macharé, J., Ortlieb, L., 1994. Morfoestratigrafia de los Tablazos del Noroeste peruano: neotectonica y fluctuaciones del nivel del mar Resumenes Extendidos del VIII Congreso Peruano de 238-241.

Marchant, S., 1961. A photogeological analysis of the structure of the western Guayas Province, Ecuador with discussion of the stratigraphy and tablazo formation derived from surface mapping. Quat. Geol. Soc. Lond. 114, 215-233. 
McLaren, S.J., Rowe, P.J., 1996. The reliability of uranium-series mollusc dates from the western Mediterranean Basin. Quat. Sci. Rev. 15, 709-717.

Mitouard, P., Kissel, C., Laj, C., 1990. Post-Oligocene rotations in southern Ecuador and northern Peru and the formation of the Huancabamba deflection in the Andean Cordillera. Earth Planet. Sci. Lett. 98, 329-339.

Mitouard, P., Laj, C., Mourier, T., Kissel, C., 1992. Paleomagnetic study of an arcuate fold belt developed on a marginal orogen: the Cajamarca deflection, northern Peru. Earth Planet. Sci. Lett. 112, $41-52$.

Mourier, T., Mégard, F., Reyes Rivera, L., Pardo Arguedas, A., 1998. L'évolution mésozoïque des Andes de Huancabamba (nord Pérousud Equateur) et l'hypothèse de l'accrétion du bloc AmotapeTahuin. Bulletin de la Société géologique de France 8 (1), 69-79.

Murray, A.S., Wintle, A.G., 2000. Luminescence dating of quartz using an improved single-aliquot regenerative-dose protocol. Radiat. Meas. 32, 57-73.

Ortlieb, L., Barrientos, S., Guzman, N., 1996. Coseismic coastal uplift and coralline algae record in Northern Chile: the 1995 Antofogasta earthquake case. Quat. Sci. Rev. 15, 949-960.

Ota, Y., 1986. Marine terraces as reference surfaces in late Quaternary tectonics studies: examples from the Pacific Rim. R. Soc. New Zealand 24, 357-375.

Palacios, O., De La Cruz, J., La Torre, O., Quispecivana, L.,1989. Mapa geologico del cuadrangulo de Paita Instituto Geografico Nacional, Lima.

Pedoja, K., Dumont, J.F., Sorel, D., Ortlieb, L., 2001. Marine terraces and subducting asperities: the Manta Case, Ecuador, Fifth International Conference on Geomorphology. Transaction of the Japanese Geomorphological Union, Tokyo, p. 187.

Pedoja, K., Dumont, J.-F., Lamothe, M., Auclair, M., 2003. Marine terraces on the north Peruvian and Ecuadorian active margin: tectonic segmentation. Geophys. Res. Abstr. 5, 12200.

Pedoja, K., Dumont, J.F., Lamothe, M.L.O., Collot, J.Y., Ghaleb, B., Auclair, M., Alvarez, V., Labrousse, B., in press. Quaternary uplift of the Manta Peninsula and La Plata Island and the subduction of the Carnegie Ridge, central coast of Ecuador. South American Journal of Earth Sciences.

Roperch, P., Megard, F., Laj, C., Mourier, T., Clube, T., Noblet, Ch., 1987. Rotated oceanic blocs in western Ecuador. Geophys. Res. Lett. 14, 558-561.

Santana, E., Armas, V., Barionuevo, C., Dumont, J.-F., King, A., Soledispa, B., 2002. Formación de una plataforma marina: cuantificación y evaluación del proceso en relación con el fenómeno El Niño, Congresso Ecuatoriano de Geologia, Guayaquil, Ecuador.

Shepherd, G., Moberly, R., 1981. Coastal structure of the continental margin, northwest Peru and southwest Ecuador. Geol. Soc. Am. Bull. 154, 351-391.

Sloss, P.W., 1994. Surface of the Earth: a computer generated image of color-shaded relief. National Geophysical Data Center. Boulder, Colorado, USA.

Trenhaile, A.S., 2001. Modeling the effect of Late Quaternary interglacial sea levels on wave-cut shore platforms. Mar. Geol. $172,205-223$.

Trenhaile, A.S., 2002. Modeling the development of marine terraces on tectonically mobile rock coasts. Mar. Geol. 185, 341-361.

Trenkamp, R., Kellogg, J.N., Freymueller, J.T., Hector Mora, P., 2002. Wide plate margin deformation, southern Central America and northwestern South America, CASA GPS observations. J. South Am. Earth Sci. 15, 157-171.

Watts, A.B., Lamb, S.H., Fairhead, J.D., Dewey, J.F., 1995. Lithospheric flexure and bending of the Central Andes. Earth Planet. Sci. Lett. 134, 9-21.

Wood, P.B., 1994. Optically stimulated luminescence dating of a late Quaternary shoreline deposit, Tunisia. Quat. Geochronol. (Quaternary Science reviews) 13, 513-516.

Zazo, C., 1999. Interglacial sea levels. Quat. Int. 55, 101-113. 